\title{
Energetic particle precipitation in ECHAM5/MESSy - Part 2: Solar proton events
}

\author{
A. J. G. Baumgaertner ${ }^{1}$, P. Jöckel ${ }^{1, *}$, H. Riede ${ }^{1}$, G. Stiller ${ }^{2}$, and B. Funke ${ }^{3}$ \\ ${ }^{1}$ Max Planck Institute for Chemistry, 55020 Mainz, Germany \\ ${ }^{2}$ Institute for Meteorology and Climate Research, Forschungszentrum Karlsruhe, Germany \\ ${ }^{3}$ Instituto de Astrofísica de Andalucía, CSIC, Granada, Spain \\ *now at: Deutsches Zentrum für Luft-und Raumfahrt (DLR), Institut für Physik der Atmosphäre, Oberpfaffenhofen, \\ 82234 Weßling, Germany
}

Received: 1 January 2010 - Published in Atmos. Chem. Phys. Discuss.: 15 February 2010

Revised: 2 July 2010 - Accepted: 28 July 2010 - Published: 6 August 2010

\begin{abstract}
The atmospheric chemistry general circulation model ECHAM5/MESSy (EMAC) has been extended by processes that parameterize particle precipitation. Several types of particle precipitation that directly affect $\mathrm{NO}_{\mathrm{y}}$ and $\mathrm{HO}_{\mathrm{x}}$ concentrations in the middle atmosphere are accounted for and discussed in a series of papers. In part 1, the EMAC parameterization for $\mathrm{NO}_{\mathrm{x}}$ produced in the upper atmosphere by low-energy electrons is presented. Here, we discuss production of $\mathrm{NO}_{\mathrm{y}}$ and $\mathrm{HO}_{\mathrm{x}}$ associated with Solar Proton Events (SPEs). A submodel that parameterizes the effects of precipitating protons, based on flux measurements by instruments on the IMP or GOES satellites, was added to the EMAC model. Production and transport of $\mathrm{NO}_{\mathrm{y}}$ and $\mathrm{HO}_{\mathrm{x}}$, as well as effects on other chemical species and dynamics during the 2003 Halloween SPEs are presented. Comparisons with MIPAS/ENVISAT measurements of a number of species affected by the SPE are shown and discussed. There is good agreement for $\mathrm{NO}_{2}$, but a severe disagreement is found for $\mathrm{N}_{2} \mathrm{O}$ similar to other studies. We discuss the effects of an altitude dependence of the N/NO production rate on the $\mathrm{N}_{2} \mathrm{O}$ and $\mathrm{NO}_{\mathrm{y}}$ changes during the SPE. This yields a modified parameterization that shows mostly good agreement between MIPAS and model results for $\mathrm{NO}_{2}, \mathrm{~N}_{2} \mathrm{O}, \mathrm{O}_{3}$, and $\mathrm{HOCl}$. With the ability of EMAC to relax the model meteorology to observations, accurate assessment of total column ozone loss is also possible, yielding a loss of approximately $10 \mathrm{DU}$ at the end of November. Discrepancies remain for $\mathrm{HNO}_{3}$, $\mathrm{N}_{2} \mathrm{O}_{5}$, and $\mathrm{ClONO}_{2}$, which are likely a consequence from
\end{abstract}

Correspondence to:

A. J. G. Baumgaertner

(work@andreas-baumgaertner.net) the missing cluster ion chemistry and ion-ion recombination in the EMAC model as well as known issues with the model's $\mathrm{NO}_{\mathrm{y}}$ partitioning.

\section{Introduction}

Solar flares and coronal mass ejections are eruptions on the sun's surface that lead to vastly increased fluxes of highenergy particles. Depending on the position of the Earth relative to the ejection, the particles can reach the earth's atmosphere. The phenomenon is then called a solar proton event (SPE). An SPE causes ionizations, dissociations, dissociative ionizations, and excitations in the atmosphere. This results in the production of $\mathrm{HO}_{\mathrm{x}}$ and $\mathrm{NO}_{\mathrm{y}}$ in the middle and upper atmosphere (Brasseur and Solomon, 1986; Jackman and McPeters, 2004). The altitude profile of the production is mainly determined by the type and number of precipitating particles and their energy distributions, which then also determines the SPE's significance in terms of associated ozone depletion through catalytic destruction by the $\mathrm{HO}_{\mathrm{x}}$ and $\mathrm{NO}_{\mathrm{x}}$ products. Such events are interesting natural experiments that allow us to test and improve our understanding of atmospheric chemistry, our observational capabilities, and numerical models.

The effects of SPEs on the middle atmosphere have been measured and modelled extensively for almost four decades, initiated by Weeks et al. (1972). Effects on $\mathrm{NO}_{\mathrm{x}}$ chemistry were first presented by Heath et al. (1977). Recently, a review on observational and modeling efforts was presented by Jackman and McPeters (2004). The fourth largest period of SPEs in the past 40 years occurred in October/November

Published by Copernicus Publications on behalf of the European Geosciences Union. 
2003 and has been termed Halloween events and received considerable attention. Jackman et al. (2005) investigated both short-term and long-term effects of the Halloween SPEs. 2-D model simulations were compared to NOAA16 SBUV/2 ozone and UARS HALOE $\mathrm{NO}_{\mathrm{x}}$ measurements. In the lower and upper mesosphere, short-term ozone depletion up to $50 \%$ and greater than $70 \%$, respectively, were found in the model results. Measurements showed a loss of approximately $40 \%$ in the lower mesosphere. Northern Hemisphere polar total ozone reduction greater than $0.5 \%$ was predicted to last for 8 months. SCIAMACHY/ENVISAT measurements of the ozone depletion were shown by Rohen et al. (2005) and Rohen et al. (2006). In addition, Rohen et al. (2005) compared the ozone depletion with results from a 2-D chemistry transport model based on SLIMCAT. In the five weeks following the SPEs the ozone depletion was captured fairly well by the model and agrees approximately with the model results of Jackman et al. (2005).

The MIPAS instrument on board ENVISAT has been used extensively to study effects of the Halloween SPE on the chemical composition of the middle atmosphere. For example, effects on $\mathrm{NO}_{\mathrm{x}}$ and ozone are shown in López-Puertas et al. (2005a), von Clarmann et al. (2005) shows HOCl and $\mathrm{ClO}$ perturbations, $\mathrm{HNO}_{3}, \mathrm{~N}_{2} \mathrm{O}_{5}$, and $\mathrm{ClONO}_{2}$ changes are discussed in López-Puertas et al. (2005b), and $\mathrm{N}_{2} \mathrm{O}$ enhancements are discussed by Funke et al. (2008). Jackman et al. (2008) noted that MIPAS measurements of the $\mathrm{HNO}_{3}$ enhancements were unexpectedly large; Verronen et al. (2008) attributed them to ion-ion recombination between $\mathrm{NO}_{3}^{-}$and $\mathrm{H}^{+}$.

Jackman et al. (2007) discussed dynamical effects in the mesosphere using results from the TIME-GCM model. SPEinduced cooling up to $2.6 \mathrm{~K}$ in the lower mesosphere and heating up to $2 \mathrm{~K}$ at $90 \mathrm{~km}$ were found. Background wind velocities changed up to $25 \%$.

The present study discusses the immediate effects of the Halloween SPEs using results from simulations with the ECHAM5/MESSy model system with an additional submodel that parameterizes the effects of SPEs in the middle atmosphere. The model results are evaluated using data from the MIPAS instrument. Disagreements between model and satellite data are attempted to be reconciled using several different options.

The model and the satellite instrument are described in Sects. 2 and 3, respectively. The simulated time evolution of several trace gases affected by the SPE as well as comparisons with the satellite observations are described in Sect. 4. Options for improvements to the parameterization are presented, and the remaining discussion is based on the parameterization that yields the best results when compared to the MIPAS measurements. Finally, a summary and conclusions are presented in Sect. 5.

\section{Model description}

\subsection{ECHAM5/MESSy}

The ECHAM/MESSy Atmospheric Chemistry (EMAC) model is a numerical chemistry and climate simulation system that includes sub-models describing tropospheric and middle atmosphere processes and their interaction with oceans, land and human influences (Jöckel et al., 2006). It uses the Modular Earth Submodel System (MESSy, see Jöckel et al., 2005; Jöckel et al., 2010) to link multiinstitutional computer codes. The core atmospheric model is the 5th generation European Centre Hamburg general circulation model (ECHAM5, Roeckner et al., 2006). The model has been shown to consistently simulate key atmospheric tracers such as ozone (Jöckel et al., 2006), water vapour (Lelieveld et al., 2007), and lower and middle stratospheric $\mathrm{NO}_{\mathrm{y}}$ (Brühl et al., 2007). For the present study we applied EMAC (ECHAM5 version 5.3.02, MESSy version $1.8^{+}$) in the T42L90MA-resolution, i.e. with a spherical truncation of T42 (corresponding to a quadratic Gaussian grid of approximately 2.8 by 2.8 degrees in latitude and longitude) with 90 vertical hybrid pressure levels up to $0.01 \mathrm{hPa}$. This part of the setup matches the model evaluation study by Jöckel et al. (2006). Enabled submodels are also the same as in Jöckel et al. (2006) apart from the new submodels SPE and SPACENOX, and the sub-submodel FUBRad (Nissen et al., 2007), a high-resolution short-wave heating rate parameterization. The submodel SPACENOX, dealing with $\mathrm{NO}_{\mathrm{x}}$ production from low-energy electrons in the upper atmosphere, is described in the companion paper (Baumgaertner et al., 2009), SPE is described here. The chosen chemistry scheme for the configuration of the submodel MECCA (Sander et al., 2005) is simpler compared to the configuration in Jöckel et al. (2006). For example, the NMHC (non-methane hydrocarbon) chemistry is not treated at the same level of detail. The complete mechanism is documented in the supplement.

The basic state of the model atmosphere is determined by a set of boundary conditions in order to make comparisons with observations more meaningful. Sea surface temperatures are taken from the Met Office Hadley Centre (HadISST), the equatorial zonal wind is weakly relaxed towards observed winds to yield the correct phase of the QBO. Long lived trace gases are relaxed towards observed concentrations at the surface, short lived species are emitted into the lowermost model layers (Baumgaertner and Brühl, 2008). The model can be nudged towards analyzed meteorology (ECMWF ERA-40), allowing direct comparisons with measurements. Results from setups that were nudged as well as from free-running setups will be shown here. Nudging was applied between levels $18(\sim 1.5 \mathrm{hPa})$ and $84(\sim 715 \mathrm{hPa})$ with relaxation e-folding times of $12 \mathrm{~h}$ for temperature, $6 \mathrm{~h}$ for vorticity, $48 \mathrm{~h}$ for divergence and $12 \mathrm{~h}$ for surface pressure. Below (down to level 13 or $\sim 0.7 \mathrm{hPa}$ ) and above (up 
to level 87 or $\sim 920 \mathrm{hPa}$ ) these levels stepwise reduced coefficients were applied.

\subsection{The submodel SPE}

The new submodel with the name SPE parameterizes the effects of energetic protons by calculating ionization rates and, subsequently, production rates of $\mathrm{NO}_{\mathrm{x}}$ and $\mathrm{HO}_{\mathrm{x}}$. The results are added to the model tendencies of $\mathrm{NO}_{\mathrm{x}}$ and $\mathrm{HO}_{\mathrm{x}}$.

A column version of the submodel was also implemented which uses the same submodel core layer files (for a discussion of the MESSy structure see Jöckel et al., 2005) as the 3-D model, but a separate interface and a simple time control. It is not coupled to any other MESSy submodels.

For the calculation of ionization rates a method based on Vitt and Jackman (1996) was employed. The proton flux measurements by GOES (Geostationary Operational Environmental Satellite) or IMP (Interplanetary Monitoring Platform) are interpolated to a logarithmic energy spectrum. The energy deposited in any model layer is calculated directly using the thicknesses of the considered layer and an energyrange relationship. Here, we used the relationship by Bethe and Ashkin (1953),

$R=(E / a)^{b}$

where $R$ is the range in meters (see Vitt and Jackman, 1996) and $E$ is the particle energy measured in $\mathrm{MeV}$. Bethe and Ashkin (1953) determined $a=9.3$ and $b=1.8$. In order to evaluate the ionization rate calculation, the SPE submodel was employed in column mode and the simulation results were compared to published ionization rates. For this, daily ionization rates provided by Jackman (2006) for the SOLARIS working group of SPARC (Stratospheric Processes and their role in climate, a project of the WCRP - World Climate Research Programme) were used as a reference. Resulting ozone depletion and other SPE effects can then be compared without large uncertainties in the underlying ionization rates. Figure 1 depicts the column model ionization rates (black lines) averaged over 28 October 2003 (dashed line) and 29 October (solid line) using hourly model output, and the data by Jackman (2006) (blue lines) for the same days. Although there is general agreement, the vertically integrated ionization rate averages for 29 October differ by $16 \%$. In particular, the ionization rate altitude dependence is not satisfactory; at $45 \mathrm{~km}$ on 29 October for example an overestimation of approximately $50 \%$ is found. However, a correct altitude dependence is crucial due to the steep profiles of ozone and other constituents that the SPE affects. Therefore, a series of sensitivity studies was performed using different sets of $a$ and $b$ in Eq. 1. Values for $a$ between 9 and 14 , for $b$ between 1 and 3 were tested. Using $a=12.3$ and $b=1.8$ yield the best agreement between the calculated and published ionization rates reducing the difference between the vertically integrated rates to $5 \%$. The results are shown as the red lines in Fig. 1. Because of the better agreement

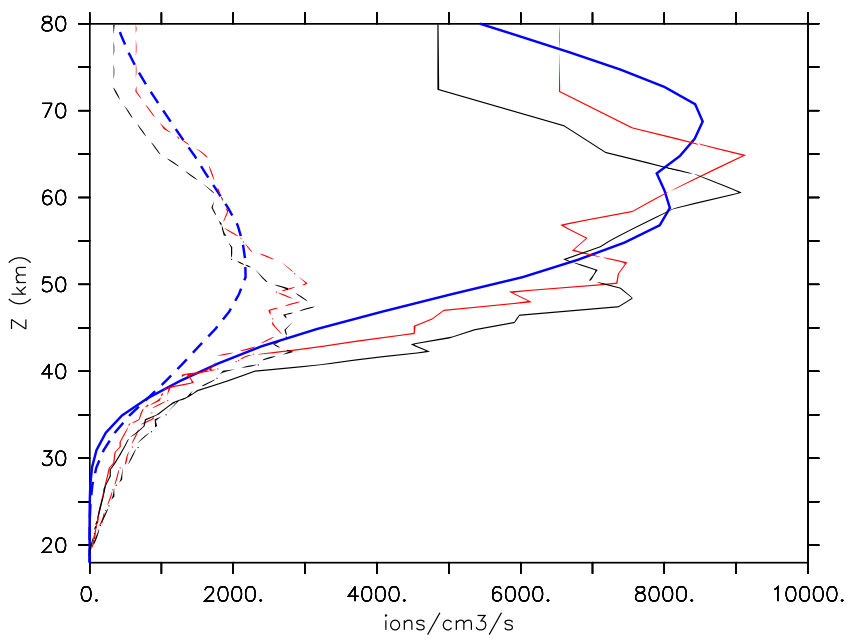

Fig. 1. Ionization rates for 28 and 29 October 2003 (dashed and solid lines, respectively) calculated by a column mode version of the SPE submodel using the original (black) and optimized (red) parameters for the energy-range relationship. Results provided by Jackman (2006) are shown in blue.

with the results by Jackman (2006) who used a more complex approach, this set of parameters was employed for the rest of this study. Note that the agreement above $50 \mathrm{~km}$ is affected by the different resolution of the data sets: the vertical resolution of EMAC in the L90 setup degrades to $8 \mathrm{~km}$ at the highest altitude.

Instead of using internally calculated ionization rates, externally calculated rates, 1-D or 3-D, generally with a lower time resolution compared to the online calculation, can also be applied. This option was however not used in the present study.

Since the magnetic field lines guide the charged particles toward the geomagnetic poles, full ionization was only applied poleward of $60^{\circ}$ geomagnetic latitude. The production of $\mathrm{N}$ and $\mathrm{NO}$ was parameterized using commonly cited values of $0.55 \mathrm{~N}$ atoms and $0.7 \mathrm{NO}$ molecules per ion pair (e.g., Jackman et al., 2005) because the model does not incorporate excited state chemistry of atomic nitrogen. However, in an attempt to improve the agreement between satellite and model results, we tested a height dependent N/NO production efficiency which is described in Sect. 4.1. The more complicated production of $\mathrm{H}$ and $\mathrm{OH}$ by ionization was parameterized using an approximation to data published in Solomon et al. (1981). $\mathrm{HO}_{\mathrm{x}}$ production per ion pair depends on altitude and the baseline ionization rate. The altitude dependence was approximated as

$f(h)=2-\exp ((h-83) / 6)$,

where $h$ is the altitude in $\mathrm{km}$. Using thresholds $t(q)$ as in Solomon et al. (1981) for the baseline ionization rate dependence, the production rates $\mathrm{H}^{\text {prod }}$ and $\mathrm{OH}^{\text {prod }}$ are then

$\left(\mathrm{H}^{\mathrm{prod}}, \mathrm{OH}^{\mathrm{prod}}\right)=0.5 \cdot q \cdot f(h) \cdot t(q)$ 
Table 1. Baseline versions for spectra version $\mathrm{V} 3 \mathrm{O}$ of the employed MIPAS data.

\begin{tabular}{lllllll}
\hline $\mathrm{O}_{3}$ & $\mathrm{HNO}_{3}$ & $\mathrm{~N}_{2} \mathrm{O}_{5}$ & $\mathrm{NO}_{2}$ & $\mathrm{~N}_{2} \mathrm{O}$ & $\mathrm{HOCl}$ & $\mathrm{ClONO}_{2}$ \\
\hline 7,9 & 8,9 & 9,10 & 9,11 & 12 & 3 & 11,12 \\
\hline
\end{tabular}

where $q$ is the ionization rate. Note that $f(h)$ cannot become negative, therefore Eq. 2 cannot be used for altitudes greater than approximately $87.2 \mathrm{~km}$.

\subsection{The CAABA boxmodel}

We also performed simulations with the atmospheric chemistry box model CAABA (Chemistry of the Atmosphere As a Box model Application, version 2.4d), described in Sander et al. (2010). CAABA contains the chemistry module MECCA (Sander et al., 2005) and the photolysis module JVAL (based on Landgraf and Crutzen, 1998), which are also part of EMAC, therefore the chemical and photochemical schemes are almost identical to the 3-D simulations. The box model does not contain heterogeneous chemistry, and the radiation environment is different in that a climatological ozone profile is assumed.

\section{Satellite observations}

The Halloween SPE effects on atmospheric chemistry have been observed by instruments on board the Environmental Satellite (ENVISAT). Here, we present measurements from the limb viewing spectrometer MIPAS (Michelson Interferometer for Passive Atmospheric Sounding) to assess if the SPE-induced production of trace gases and subsequent ozone depletion as seen in the model output are realistic. MIPAS observations of the Halloween SPE have previously been presented for example by López-Puertas et al. (2005a), LópezPuertas et al. (2005b), von Clarmann et al. (2005) and Funke et al. (2008). Here, we use the retrievals performed with the IMK-IAA data processor and the Karlsruhe Optimized and Precise Radiative Transfer Algorithm (KOPRA), which were also used in the aforementioned MIPAS studies.

Only MIPAS spectra version V3O were employed. The employed baseline versions are listed in Table 1. The differences between the employed baseline versions are small and generally simply cover different days of the concerned period. When several versions were available for a specific day, the newest version was employed.

The MIPAS measurement errors and vertical resolution for a single profile are listed in Table 2 for $40 \mathrm{~km}$ and $60 \mathrm{~km}$ altitude. Note that if an ensemble of measurements is considered, the precision of the mean (also termed random error) is reduced by a factor equal to the square root of the number of measurements. The systematic error and the vertical resolution do not change with the number of measurements. Ad- ditionally, the standard error of an ensemble mean needs to be considered, which accounts for natural variability as well as measurement precision. During highly disturbed conditions, such as for $\mathrm{NO}_{2}$ during the initial phase of an SPE, the standard error can be much larger than the precision. The sampling "error", i.e. the error related to the fact that only a limited number of measurement points in time and space of a "true distribution" exist, has not been quantified. Note, however, that due to the relatively homogeneous spread of MIPAS profiles over the polar area the difference between the measured and modelled distributions should be small. For the sampling in time, only species with a large diurnal cycle are likely to be adversely affected by this as discussed below.

To facilitate comparison with the model results, the MIPAS data were binned to create a daily time series. The data were also gridded onto the EMAC model grid used here (T42). No restrictions were made with respect to solar zenith angle limits and both day and night data were used. For species with a strong diurnal cycle, here especially $\mathrm{NO}_{2}$, this is a potential error source if the fraction of measurement points made during sunlit conditions is different between model and measurements. For example, for $\mathrm{NO}_{2}$ we found for 31 October in the region poleward of $70^{\circ} \mathrm{N}$ a daytime fraction of $10 \%$ for EMAC, and 13\% for MIPAS, both calculated from the solar zenith angle. Differences of the same magnitude persist until mid-November when the area north of $70^{\circ} \mathrm{N}$ remains completely dark. Therefore, in the first half of November this introduces a negative bias for MIPAS $\mathrm{NO}_{2}$ compared to EMAC, as more profiles were obtained in daylight when $\mathrm{NO}_{2}$ is negligible.

In the vertical, the original geometric height grid was adopted as is. For comparison with the MIPAS data, the model output was transferred onto the same vertical grid using the simulated geopotential height.

The vertical resolution of the MIPAS data is generally lower than the model vertical resolution. Therefore, the model results were convolved with the corresponding MIPAS averaging kernel (AK). The supplement contains figures with and without convolution with the MIPAS AK.

\section{Results and discussion}

The SPE submodel has been tested with EMAC for the time of the Halloween SPEs between 28 October and 4 November 2003. For the most intense period, 28-31 October 2003, the zonally averaged $\left(70^{\circ}-90^{\circ} \mathrm{N}\right)$ ionization rate profiles are depicted as a function of time in Fig. 2. The major episode of the SPE starts at approximately 12:00 UTC on 28 October 2003 . Above $40 \mathrm{~km}$ altitude the ionization rate exceeds 10000 ion pairs $\mathrm{cm}^{-3} \mathrm{~s}^{-1}$ for several hours on 29 October 2003. Less intense periods follow on the 30 October and 2-4 November. There appears to be a very good agreement with the ionization rates calculated by Jackman et al. (2005), see their Fig. 3. 
Table 2. MIPAS measurement error contributions and vertical resolution.

\begin{tabular}{|c|c|c|c|c|c|c|}
\hline & \multicolumn{2}{|c|}{$\begin{array}{l}\text { Single profile precision for } 70-90^{\circ} \mathrm{N} \text {; given in } \\
\text { vmr and percent under quiet and disturbed (in } \\
\text { brackets, } 30 \text { October }-5 \text { November) conditions }\end{array}$} & \multicolumn{2}{|c|}{ Systematic error } & \multicolumn{2}{|c|}{$\begin{array}{l}\text { Vertical resolution }(\mathrm{km}) \text { for } \\
70-90^{\circ} \mathrm{N}\end{array}$} \\
\hline & $40 \mathrm{~km}$ & $60 \mathrm{~km}$ & $40 \mathrm{~km}$ & $60 \mathrm{~km}$ & $40 \mathrm{~km}$ & $60 \mathrm{~km}$ \\
\hline $\mathrm{O}_{3}$ & $0.26 \mathrm{ppmv} / 6(6) \%$ & $0.11 \mathrm{ppmv} / 10(14) \%$ & $0.33 \mathrm{ppmv}$ & $0.0067 \mathrm{ppmv}$ & 4 & 9 \\
\hline $\mathrm{HNO}_{3}$ & $0.15 \mathrm{ppbv} / 9(7) \%$ & $0.37 \mathrm{ppbv} / 42(22) \%$ & $0.30 \mathrm{ppbv}$ & $0.32 \mathrm{ppbv}$ & 8 & 43 \\
\hline $\mathrm{N}_{2} \mathrm{O}_{5}$ & $0.18 \mathrm{ppbv} / 18(40) \%$ & $0.041 \mathrm{ppbv} / 54(90) \%$ & $0.064 \mathrm{ppbv}$ & $0.0081 \mathrm{ppbv}$ & 7 & 52 \\
\hline $\mathrm{N}_{2} \mathrm{O}$ & $0.63 \mathrm{ppbv} / 45(67) \%$ & $0.46 \mathrm{ppbv} / 26(15) \%$ & $0.027 \mathrm{ppbv}$ & $0.45 \mathrm{ppbv}$ & 4 & 13 \\
\hline $\mathrm{NO}_{2}$ & $1.7 \mathrm{ppbv} / 11(13) \%$ & $4.6 \mathrm{ppbv} / 9(10) \%$ & $0.86 \mathrm{ppbv}$ & $5.1 \mathrm{ppbv}$ & 7 & 13 \\
\hline $\mathrm{HOCl}$ & $0.12 \mathrm{ppbv} / 63(44) \%$ & $0.0019 \mathrm{ppbv} / 70(50) \%$ & $0.0013 \mathrm{ppbv}$ & $0.000049 \mathrm{ppbv}$ & 15 & 17 \\
\hline $\mathrm{ClONO}_{2}$ & $0.13 \mathrm{ppbv} / 17(14) \%$ & $0.02 \mathrm{ppbv} / 40(31) \%$ & $0.069 \mathrm{ppbv}$ & $0.0063 \mathrm{ppbv}$ & 13 & 16 \\
\hline
\end{tabular}

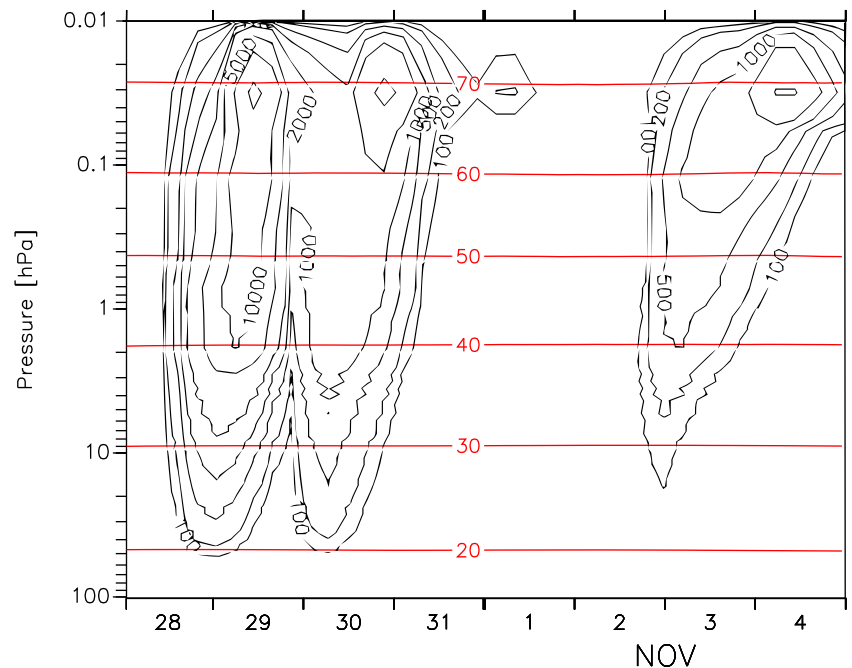

Fig. 2. Calculated high-latitude $\left(70^{\circ}-90^{\circ} \mathrm{N}\right.$ zonal average) ionization rates $\left(\# \mathrm{~cm}^{-3} \mathrm{~s}^{-1}\right)$ during October and November 2003. The red lines denote the altitude in $\mathrm{km}$.

In addition to the simulation with the SPE submodel switched on (denoted S-SPE in this paper), one simulation was performed without the submodel (denoted S-NOSPE). This allows to accurately assess the impact of the SPE by comparing the two simulations with each other. Both simulations were nudged towards the observed meteorology in the troposphere (see Sect. 2), so differences in the dynamics of the two simulations are small.

Before we present an analysis of trace gases that are affected by the Halloween SPEs, we discuss the simulated and observed temperatures before and during the events. Because many reactions involving $\mathrm{NO}_{\mathrm{y}}$ species are temperature dependent, it is important to know how accurately the temperature is simulated by the model. In Fig. 3 the EMAC temperatures between 26 October and 30 November 2003 are directly compared to MIPAS measurements at altitudes between 38 and $66 \mathrm{~km}$ at $4 \mathrm{~km}$ intervals. All altitude bins can be distinguished by a different colour and symbol and are

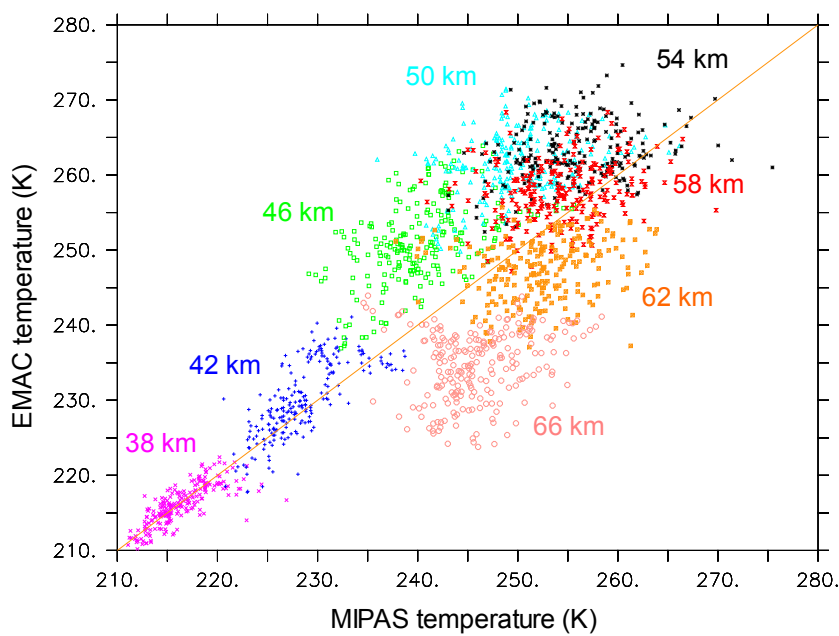

Fig. 3. Comparison of zonal average temperatures of MIPAS and EMAC for $70-90^{\circ} \mathrm{N}$ for 26 October-30 November 2003.

labelled accordingly. In the upper stratosphere between 46 and $54 \mathrm{~km}$ a high bias of approximately $10 \mathrm{~K}$ can be noted (the model stratopause is situated at approximately $53 \mathrm{~km}$, not shown). Higher up, the model shows a low bias increasing with altitude to $10 \mathrm{~K}$ at $66 \mathrm{~km}$. These biases indicate that the model stratopause is lower than in the observations and are likely to affect the comparisons of simulated and measured trace gas concentrations, therefore sensitivity studies using a boxmodel with fixed temperatures are presented in Sect. 4.1.

Atomic nitrogen $(\mathrm{N})$ and nitric oxide (NO) are among the direct products of the SPE, and the effects on $\mathrm{NO}_{\mathrm{x}}$ are discussed and evaluated next. Figure 4 depicts changes in $\mathrm{NO}_{2}$ with respect to 26 October for $70-90^{\circ} \mathrm{N}$ from MIPAS measurements (Fig. 4a) and the corresponding model results with the MIPAS $\mathrm{NO}_{2}$ averaging kernel applied (Fig. 4b). Note that day and night data were used to create this figure and similar figures below. 


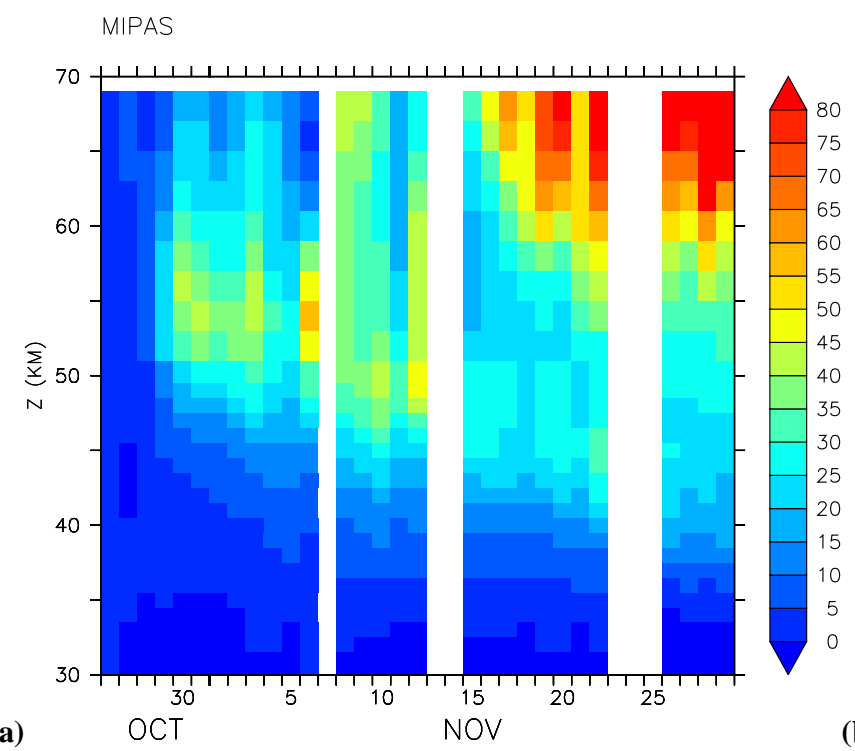

(b)

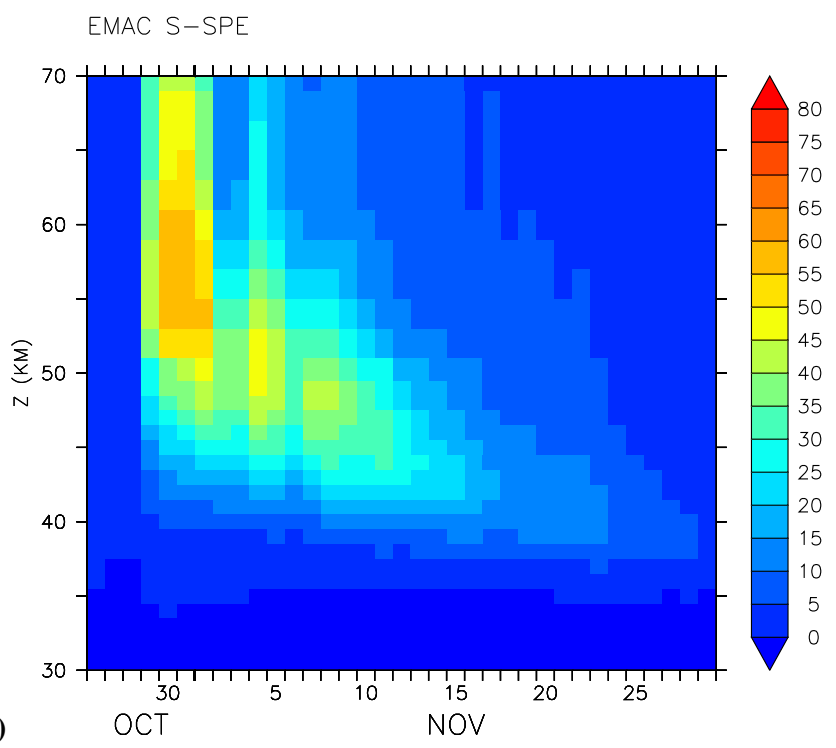

Fig. 4. $\mathrm{NO}_{2}$ change (ppbv) with respect to 26 October for $70-90^{\circ} \mathrm{N}$ for (a) MIPAS, (b) EMAC simulation S-SPE.

During the SPE, MIPAS shows lower mesospheric enhancements up to $50 \mathrm{ppbv}$ where the model reaches $60 \mathrm{ppbv}$. During the initial phase of the SPE the $\mathrm{NO}_{\mathrm{x}}$ enhancements are centered around the geomagnetic pole, then gradually transported and mixed to other areas including lower latitudes (not shown). This leads to a very inhomogeneous spatial distribution of $\mathrm{NO}_{\mathrm{x}}$ and thus large sampling errors (see Sect. 3). Also note that the systematic error of $\mathrm{NO}_{2}$ at $60 \mathrm{~km}$ is $5.1 \mathrm{ppbv}$ (see Table 2). In the light of these aspects, the agreement between EMAC and MIPAS is acceptable. Higher up the model overestimates the enhancements by up to $100 \%$. In the following weeks downward transport of the enhancements can be seen in both the model results and the measurements. Note that the enhancements in the MIPAS data in the upper mesosphere during the second half of November are not related to in-situ production of $\mathrm{NO}_{\mathrm{x}}$ but originate in the lower thermosphere and are transported downward. This effect is not subject of the work presented here, but is discussed in the companion paper by Baumgaertner et al. (2009). Also note that on 6 and 7 November only 5 profiles were obtained by MIPAS in this area, with an ensemble mean precision of $1.5 \mathrm{ppbv}$ at $50 \mathrm{~km}$. Similarly, on 12 and 13 November only 6 profiles were obtained, with an ensemble mean precision of $1.0 \mathrm{ppbv}$. Therefore the enhancements during both these periods are probably not representative for the full polar cap, given that flux measurements did not show any anomalies during these times.

The produced $\mathrm{NO}_{\mathrm{x}}$ can partially react to form $\mathrm{N}_{2} \mathrm{O}$ as has been shown e.g. by Funke et al. (2008). Figure 5 depicts $\mathrm{N}_{2} \mathrm{O}$ changes in MIPAS and model data similar to the $\mathrm{NO}_{2}$ changes shown above. It is evident that the model production of $\mathrm{N}_{2} \mathrm{O}$ by far exceeds that of the enhancements observed by MIPAS. The measurements show enhancements below $5 \mathrm{ppbv}$, while in the model $35 \mathrm{ppbv}$ are reached at $60 \mathrm{~km}$ (not discernable from Fig. 5 due to the saturated scale which was chosen such that the MIPAS measurements can be analysed). This is a major deficiency of the model performance during this event and has been found in other model simulations as well (Funke et al., 2008). Before the effects on other species are discussed, possible options for improvements to the model or the SPE parameterization are explored in the next section.

\subsection{Model improvements}

The large discrepancy between simulated and observed $\mathrm{N}_{2} \mathrm{O}$ could be due to various reasons:

1. reactions not accounted for or unknown, or inaccurate reaction rates,

2. incorrect external parameters that influence the reactions, such as temperature, or

3. inaccurate assumptions about SPE production of N/NO.

A similar discrepancy between MIPAS $\mathrm{N}_{2} \mathrm{O}$ and the Canadian Middle Atmosphere Model (CMAM) during the Halloween storm period was reported by Funke et al. (2008). They attempted to resolve this problem by adding to the $\mathrm{N}_{2} \mathrm{O}$-forming reaction (reaction $\mathrm{G} 3107$ in the MECCA mechanism, see supplement.)

$\mathrm{N}\left({ }^{4} \mathrm{~S}\right)+\mathrm{NO}_{2} \rightarrow \mathrm{N}_{2} \mathrm{O}+\mathrm{O}$

the branches

$\mathrm{N}\left({ }^{4} \mathrm{~S}\right)+\mathrm{NO}_{2} \rightarrow \mathrm{NO}+\mathrm{NO}$ 

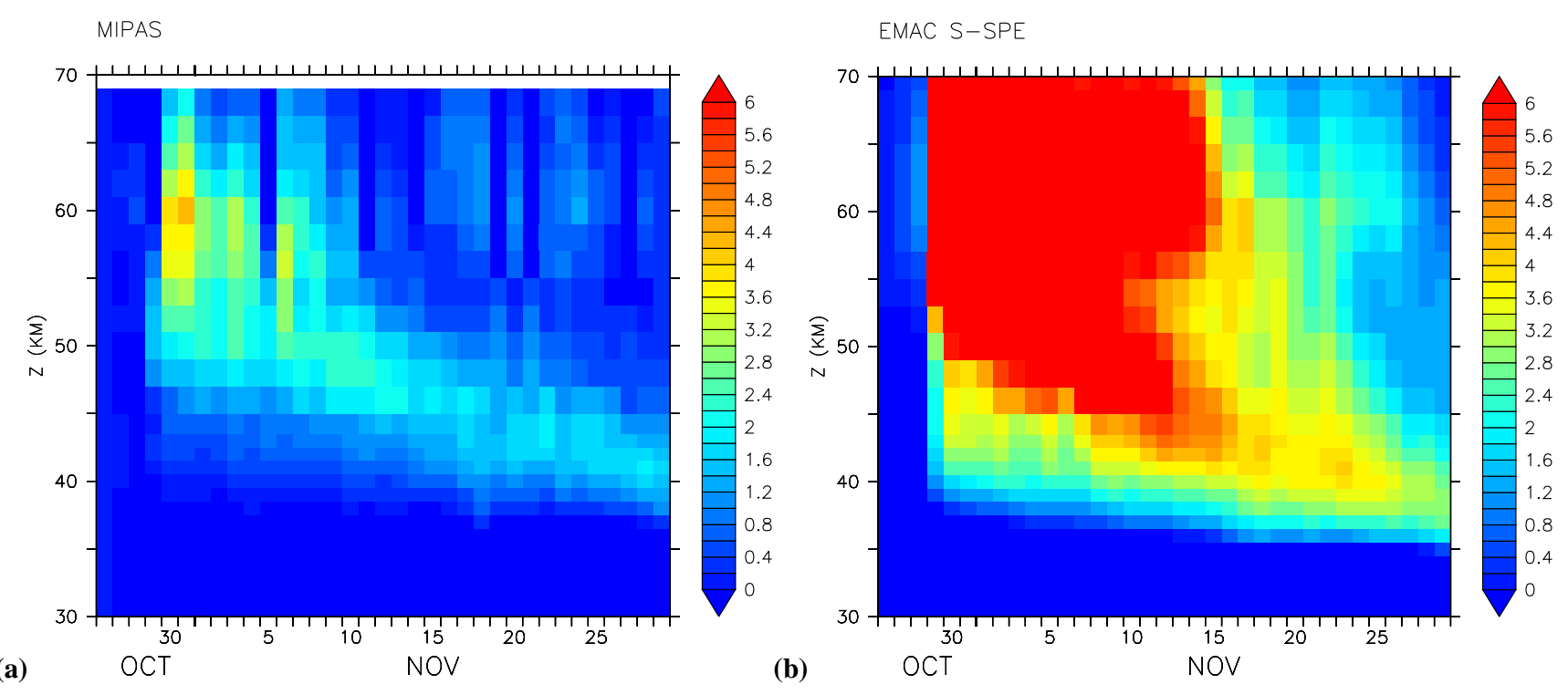

Fig. 5. Same as Fig. 4 but for $\mathrm{N}_{2} \mathrm{O}$ (ppbv).

$$
\mathrm{N}\left({ }^{4} \mathrm{~S}\right)+\mathrm{NO}_{2} \rightarrow \mathrm{N}_{2}+\mathrm{O}_{2}
$$

with $50 \%$ of the reaction rate going into the primary branch $\mathrm{R} 1$, and $25 \%$ each for the Reactions (R2) and (R3) chosen such that the model better reproduces the observations. The same modification was implemented in EMAC (see supplement) and the equivalent simulation to S-SPE was performed, termed S-SPE-FUNKE hereafter. The results for $\mathrm{N}_{2} \mathrm{O}$ are shown in Fig. 6. There is generally less $\mathrm{N}_{2} \mathrm{O}$ compared to the S-SPE simulation discussed above (Fig. 5), however, a large overestimation persists.

The second possibility listed above refers to external parameters that influence the production of $\mathrm{N}_{2} \mathrm{O}$. The Reaction (R1) that forms $\mathrm{N}_{2} \mathrm{O}$ after the SPE is temperature dependent with a rate coefficient of

$k=5.8 \times 10^{-12} \cdot e^{220 / T}$

(see supplement), therefore the temperature discrepancy found above (see Fig. 3) could explain some of the overestimations of $\mathrm{N}_{2} \mathrm{O}$. This hypothesis is tested by performing sensitivity simulations of the chemistry only. For this, the boxmodel CAABA, described in Sect. 2.3, is used. CAABA was initialized with the temperature and tracer mixing ratios of the corresponding spatial and temporal location in the 3-D simulation. Note that the temperature is kept constant throughout the CAABA simulation. The solar proton event was simulated by applying the ionization rates that were calculated in the 3-D study. Temperature sensitivity of the reactions was explored by offsetting the temperature $T_{\text {caaba }}$ with respect to the 3-D simulation $T_{3-D}$. As an example, the resulting $\mathrm{N}_{2} \mathrm{O}$ mixing ratios for a CAABA simulation for $60 \mathrm{~km}$ altitude, $0^{\circ} \mathrm{E}$, and $75^{\circ} \mathrm{N}$ are shown in Fig. 7 for the temperature $T_{3-\mathrm{D}}$ (black), as well as for $T_{3-\mathrm{D}}+10 \mathrm{~K}$ (red) and

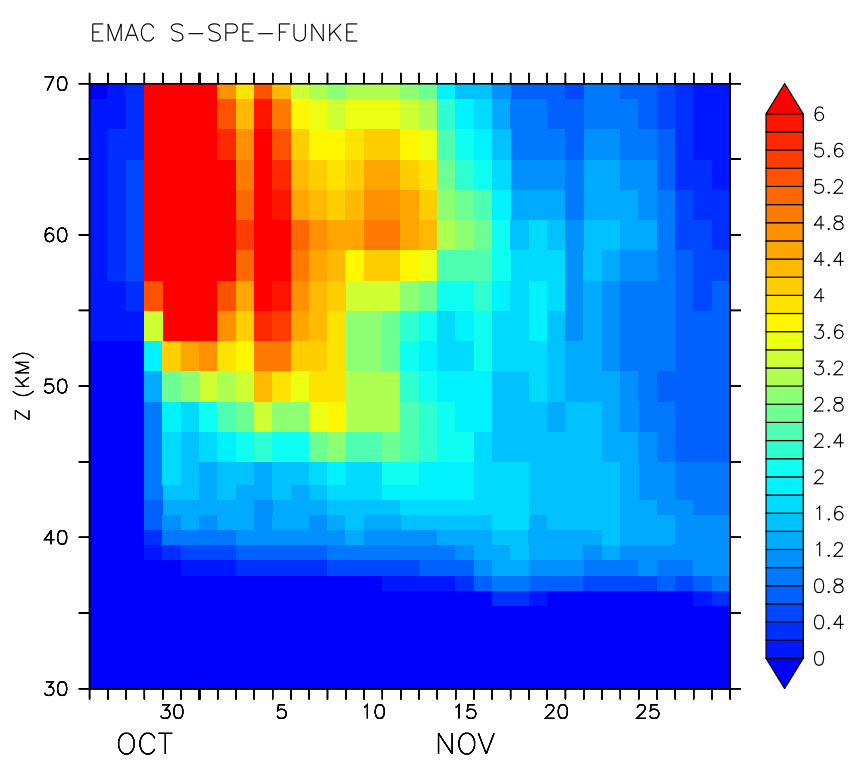

Fig. 6. $\mathrm{N}_{2} \mathrm{O}$ change (ppbv) in EMAC simulation S-SPE-FUNKE with respect to 26 October for $70-90^{\circ} \mathrm{N}$.

$T_{3-\mathrm{D}}+20 \mathrm{~K}$ (green). The crosses denote MIPAS measurements in the area $75^{\circ} \mathrm{N} \pm 5^{\circ}$ latitude.

As expected from the 3-D simulation with the same chemical mechanism, there is a sharp increase of $\mathrm{N}_{2} \mathrm{O}$ during the SPE, but no change in the following weeks since there is no $\mathrm{N}_{2} \mathrm{O}$ photolysis and no $\mathrm{O}\left({ }^{1} \mathrm{D}\right)$ present to deplete $\mathrm{N}_{2} \mathrm{O}$. A significant temperature dependence of the amount of $\mathrm{N}_{2} \mathrm{O}$ produced is evident. However, mixing ratios are still strongly overestimated when compared to the MIPAS observations. 


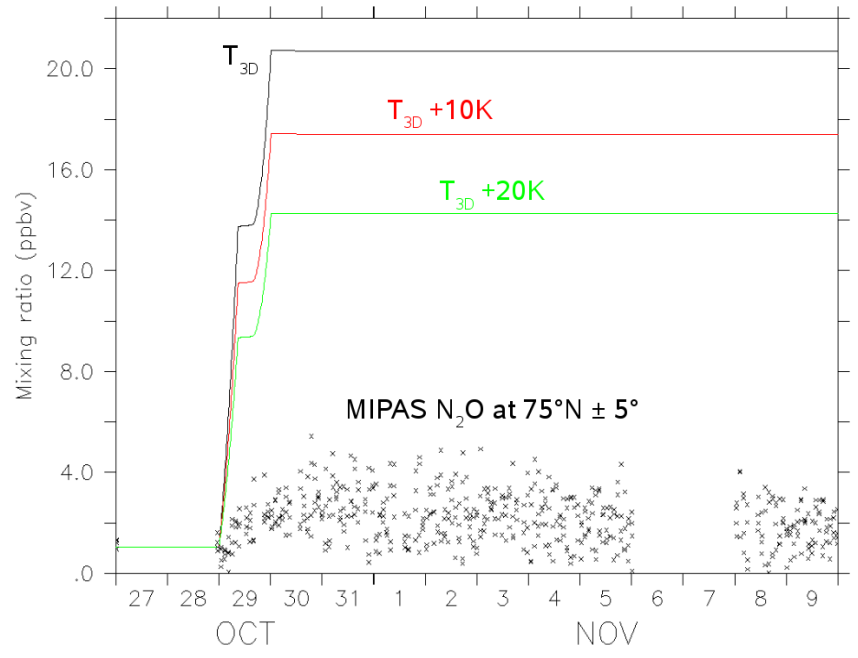

Fig. 7. Mixing ratios of $\mathrm{N}_{2} \mathrm{O}$ at $60 \mathrm{~km}, 75^{\circ} \mathrm{N}$ from the CAABA box model at three different temperatures (lines), and MIPAS $\mathrm{N}_{2} \mathrm{O}$ measurements for the same latitude region.

Finally, we discuss the third possibility, referring to inaccurate assumptions about the production efficiency of $\mathrm{N}$ and NO per ion pair.

We have chosen this branching ratio as tuning parameter because neither experiments nor theoretical studies have provided accurate values by now. Values ranging from 0.33 to 2.5 for the total production of $\mathrm{N}$ and $\mathrm{NO}$ have been reported in previous work. Thus, its adjustment by means of a fit to MIPAS data is appropriate as long as the resulting branching ratio does not significantly exceed the spread of values reported in the literature. It should be noted, however, that we do not aim at providing a scientific justification for modification of this parameter (which would be beyond the scope of this paper) but at identifying potential error sources responsible for the model/data mismatch and - in this sense - to motivate future experimental studies.

The method presented here, which is used to reconcile $\mathrm{N}_{2} \mathrm{O}$ concentrations, appears to be a manifest approach because the $0.55 \mathrm{~N}\left({ }^{4} \mathrm{~S}\right) / 0.7 \mathrm{NO}$ branching ratio commonly used has only been derived by "best fit" between models and observations in the past. We support this statement with the following discussion of the involved processes and of previous studies on this subject.

Impacting protons with energies from $100 \mathrm{keV}$ to $1 \mathrm{GeV}$ that reach the mesosphere or stratosphere are too energetic to be efficient in dissociating nitrogen (Crutzen et al., 1975), but deposit their energy in the accessible states of $\mathrm{N}_{2}$ and $\mathrm{O}_{2}$ by secondary electrons of low energy $(<100 \mathrm{eV})$, see Porter et al. (1976). These act on $\mathrm{N}_{2}$ and $\mathrm{O}_{2}$ to initially produce $\mathrm{N}$, $\mathrm{N}^{+}, \mathrm{N}_{2}^{+}, \mathrm{O}, \mathrm{O}^{+}$, and $\mathrm{O}_{2}^{+}$; for details on these reactions see e.g. Rusch et al. (1981). Further reactions lead to the production of $\mathrm{N}\left({ }^{4} \mathrm{~S}\right), \mathrm{N}\left({ }^{2} \mathrm{D}\right)$, and $\mathrm{N}^{+}$(which via reaction with $\mathrm{O}_{2}$ also reacts further to $\mathrm{N}\left({ }^{2} \mathrm{D}\right)$ ) as well as other electroni- cally excited states of $\mathrm{N}$ and $\mathrm{O}$ probably of less importance (for nitrogen: $\mathrm{N}\left({ }^{2} \mathrm{P}\right), \mathrm{N}\left(3 \mathrm{~s}^{2} \mathrm{P}\right), \mathrm{N}\left(3 \mathrm{~s}^{4} \mathrm{P}\right), \mathrm{N}\left(3 \mathrm{~s}^{2} \mathrm{D}\right), \mathrm{N}\left(4 \mathrm{~s}^{2} \mathrm{P}\right)$ ). Note that several of the involved reaction rates and branching ratios have not been experimentally determined (Rusch et al., 1981). The following reactions then lead to the formation of NO:

$\mathrm{N}\left({ }^{4} \mathrm{~S}\right)+\mathrm{O}_{2} \rightarrow \mathrm{NO}+\mathrm{O}$

$\mathrm{N}\left({ }^{2} \mathrm{D}\right)+\mathrm{O}_{2} \rightarrow \mathrm{NO}+\mathrm{O}$.

Reaction (R4) is slow and highly temperature dependent, while Reaction (R5) is fast and thus the main source for NO. Additionally, $\mathrm{N}\left({ }^{2} \mathrm{D}\right)$ can react with $\mathrm{O}$ or $\mathrm{NO}$ :

$\mathrm{N}\left({ }^{2} \mathrm{D}\right)+\mathrm{O} \rightarrow \mathrm{N}\left({ }^{4} \mathrm{~S}\right)+\mathrm{O}$

$\mathrm{N}\left({ }^{2} \mathrm{D}\right)+\mathrm{NO} \rightarrow \mathrm{N}_{2}+\mathrm{O}$.

Additional to the Reaction (R1), $\mathrm{N}\left({ }^{4} \mathrm{~S}\right)$ also takes part in the following reactions:

$\mathrm{N}\left({ }^{4} \mathrm{~S}\right)+\mathrm{NO} \rightarrow \mathrm{N}_{2}+\mathrm{O}$

$\mathrm{N}\left({ }^{4} \mathrm{~S}\right)+\mathrm{NO}_{2} \rightarrow \mathrm{N}_{2} \mathrm{O}+\mathrm{O}$

Many atmospheric chemistry models do not include ion or detailed excited state chemistry, so in order to parameterise solar proton events, the formation of ground state $\mathrm{N}$ and $\mathrm{NO}$ is required as a function of ionization rate. However, because of reactions (R5) and (R6) it is not possible to assume an NO production rate normalized to the ionization rate, as pointed out e.g. by Rusch et al. (1981). We would also like to point out that the branching ratio $\mathrm{N}\left({ }^{4} \mathrm{~S}\right) / \mathrm{N}\left({ }^{2} \mathrm{D}\right)$ is not necessarily equal to the ratio $\mathrm{N}\left({ }^{4} \mathrm{~S}\right) / \mathrm{NO}$ because of the additional reactions listed above.

Crutzen et al. (1975) mentioned that from the experimental studies of Winters (1966), Rapp et al. (1965), and Rapp and Englander-Golden (1965) a rate of production of $1.5 \mathrm{~N}$ atoms per ion pair can be estimated. However, the ratio $\mathrm{N}\left({ }^{4} \mathrm{~S}\right) / \mathrm{N}\left({ }^{2} \mathrm{D}\right)$ or $\mathrm{N}\left({ }^{4} \mathrm{~S}\right) / \mathrm{NO}$ was not determined. Porter et al. (1976) write that additional studies concerning atomic nitrogen production were limited to high energy secondary electrons $(>100 \mathrm{keV})$ and are thus not applicable for SPEs. The work of Porter et al. (1976) is the only theoretical study that used an atomic cross section approach to derive a production of 1.27 atoms per ion pair for proton impact at $1 \mathrm{MeV}$, distributed over 8 different states including $\mathrm{N}^{+}$(see their Table $\mathrm{V})$. While the ratio of $\mathrm{N}\left({ }^{4} \mathrm{~S}\right) / \mathrm{N}\left({ }^{2} \mathrm{D}\right)$ can be deduced from this, it is not possible to accurately derive the N/NO production ratio. It is also interesting to note that Porter et al. (1976) found that, "it is observed that the efficiency for production of atomic species changes with the particle energy", which effectively means that such production at least for proton energies below $1 \mathrm{MeV}$ is height dependent since the particle energy determines the height it reaches. 
As discussed in the following, newer SPE studies generally base their branching ratios either on approximations to Porter et al. (1976), often assuming that the ratio $\mathrm{N}\left({ }^{4} \mathrm{~S}\right) / \mathrm{NO}$ ratio is equal or similar to the $\mathrm{N}\left({ }^{4} \mathrm{~S}\right) / \mathrm{N}\left({ }^{2} \mathrm{D}\right)$ ratio, or derive such branching ratios by fitting their model results to observations. A review article by Jackman and McPeters (2004) states "Estimates of the number of $\mathrm{NO}_{\mathrm{y}}$ constituents created per ion pair range from 0.33 (Warneck, 1972) up to 2.5 (Fabian et al., 1979). Recent publications show only small differences and range from 1.25 (Jackman et al. 1990) up to 1.3 (Reid et al., 1991) $\mathrm{NO}_{\mathrm{y}}$ constituents produced per ion pair." The study by Fabian et al. (1979) based their assumption on rocket measurements of mesospheric and thermospheric NO concentrations as well as ionisation rates. The work by Warneck (1972) is a modeling study based on production rates of 0.64 for $\mathrm{N}_{2}^{+}$and 0.16 for $\mathrm{N}^{+}$as published by Dalgarno (1967). However, Dalgarno (1967) derived from the initial $\mathrm{N}_{2}^{+}$and $\mathrm{N}^{+}$creation a production of $0.8 \mathrm{~N}$ and 0.5 $\mathrm{NO}$ "with a possible doubling of [the production rate of] NO at night", which is in disagreement with the $0.33 \mathrm{NO}_{\mathrm{y}}$ constituents derived by Warneck (1972).

Reid et al. (1991) indeed use a value of $1.3 \mathrm{NO}_{\mathrm{y}}$ molecules per ion pair: "Following Rusch et al, 1981, we assume that $1.3 \mathrm{NO}_{\mathrm{y}}$ molecules are produced per ion pair, partitioned between the ground $\mathrm{N}\left({ }^{4} \mathrm{~S}\right)$ state and exited states (mainly 2-D) at 20 and 80\%." The Rusch et al. (1981) paper is a theoretical study that includes a comparison of model results and observations, however, they base their results on several assumptions that were not experimentally verified, and their conclusions are also build on "best fit" to observations: "A production of 1.3 odd nitrogens per ion par, an $80 \%$ branching ratio for the production of $\mathrm{N}\left({ }^{2} \mathrm{D}\right)$ by the primary reactions dissociating $\mathrm{N}_{2}$, and inclusion of the loss of $\mathrm{NO}_{\mathrm{x}}$ through $\mathrm{N}+\mathrm{NO}$ in a time-dependent calculation appears to produce an ozone destruction most compatible with the measurements." The other study cited in Jackman and McPeters (2004) is Jackman et al. (1990). They state "This calculation assumed 1.25 nitrogen $(\mathrm{N})$ atoms produced per ion pair which is similar to the value given by Porter et al. (1976), derived using a detailed theoretical energy degradation computation. The agreement between the predicted and measured NO increase following the July 1982 SPE has given us confidence in the reliability of the computations for $\mathrm{NO}_{\mathrm{y}}$ species increase caused by SPEs. We therefore assume that $1.25 \mathrm{~N}$ atoms are produced per ion pair for all base model computations in this paper."

The N/NO branching is discussed in a newer modeling study by Jackman et al. (2005) who state "In order to best represent the production of $\mathrm{NO}_{\mathrm{y}}$ constituents by the protons and their associated secondary electrons, we assume that $45 \%$ of the $\mathrm{N}$ atoms produced per ion pair result in the production of $\mathrm{N}\left({ }^{4} \mathrm{~S}\right)(\sim 0.55$ per ion pair) and that $55 \%$ of the $\mathrm{N}$ atoms produced per ion pair result in the production of NO ( $~ 0.7$ per ion pair)." It appears that this choice is also based on a best fit to observations of $\mathrm{NO}_{\mathrm{y}}$.
We conclude, that established $\mathrm{N}\left({ }^{4} \mathrm{~S}\right) / \mathrm{NO}$ ratios are not firmly supported by theoretical or experimental work or are inconsistent.

However, the observed discrepancy of $\mathrm{N}_{2} \mathrm{O}$ could possibly be resolved by changing the $\mathrm{N} / \mathrm{NO}$ branching ratio since the amount of produced $\mathrm{N}_{2} \mathrm{O}$ is mostly dependent on the amount of available $\mathrm{N}$ atoms. Reducing the number of $\mathrm{N}$ atoms produced by an ion pair would therefore yield better results for $\mathrm{N}_{2} \mathrm{O}$. Since the 3-D model is computationally too expensive to perform a large number of tests of other N/NO production efficiencies, the following approach was chosen. The boxmodel CAABA, described in Sect. 2.3, was used to simulate the SPE at MIPAS measurement locations for $\mathrm{N}$ and NO production per ion pair ranging from 0 to 1.2 using steps sizes of 0.05 . There are approximately 200 MIPAS profiles of $\mathrm{N}_{2} \mathrm{O}$ and $\mathrm{NO}_{2}$ between 31 October and 2 November north of $70^{\circ} \mathrm{N}$ available, all of which were included in this simulation set. Such a short period was chosen in order to avoid strong contributions by vertical transport, which cannot be captured by CAABA. The simulations were performed at $4 \mathrm{~km}$ height intervals starting at $42 \mathrm{~km}$.

For each simulation CAABA was initialized at 27 October, one day before the SPE, with the temperature and tracer mixing ratios of the corresponding spatial and temporal location in the 3-D simulation. As in the CAABA simulations above, the SPE was simulated by applying the ionization rates that were calculated in the 3-D study. The simulation was stopped at the time step closest to the MIPAS measurement. Then the percentage deviations from the MIPAS values of both species were calculated. From all deviations the median was calculated separately for $\mathrm{NO}_{2}$ and $\mathrm{N}_{2} \mathrm{O}$. Finally, the two medians were averaged using equal weighting. The entire simulation and processing chain is depicted in Fig. 8. It also shows the average deviations for $58 \mathrm{~km}$ altitude. From this, the $\mathrm{N}$ and NO productions per ion pair minimizing the total deviation was determined. Figure 9, left, shows the resulting production per ion pair for $\mathrm{N}$ (filled circles) and NO (filled squares), also indicating the remaining total deviation in percent. On the right, Fig. 9 shows the ratio of N/NO production.

At $42 \mathrm{~km}$, the remaining total deviation is still large (83\%), but is below $10 \%$ at 46,50 , and $58 \mathrm{~km}$. At $62 \mathrm{~km}$, where the model vertical resolution and the agreement of the ionization rates (see Fig. 1) degrade, deviations rise again up to $40 \%$. Generally, there appears to be a strong height dependence, with an almost negligible production of $\mathrm{N}$ atoms below 45 which is in disagreement with the generally assumed production parameterization of $0.55 \mathrm{~N}$ atoms. Above $55 \mathrm{~km}$ the production of $\mathrm{NO}$ is also in disagreement with the previously used value of 0.7 . This is mainly due to the fact that MIPAS yields only small increases of $\mathrm{NO}_{2}$ and $\mathrm{N}_{2} \mathrm{O}$ at these altitudes, despite the large ionization rates present there. This discrepancy can only partially be explained by the MIPAS averaging kernels for $\mathrm{NO}_{2}$ and $\mathrm{N}_{2} \mathrm{O}$ and warrants further investigation. Note that the production of $\mathrm{N}$ and $\mathrm{NO}$ per ion pair, as well as the $\mathrm{N} / \mathrm{NO}$ production ratio appear to 
MIPAS measurement locations

at latitudes $>70^{\circ} \mathrm{N}, 31$ Oct -2 Nov 2003

$\begin{array}{ll}\text { for } \mathrm{N}_{\text {per ion pair }}= & 0 . .1 .2 \\ \text { and } \mathrm{NO} \mathrm{O}_{\text {per ion pair }}= & 0 . .1 .2\end{array}$

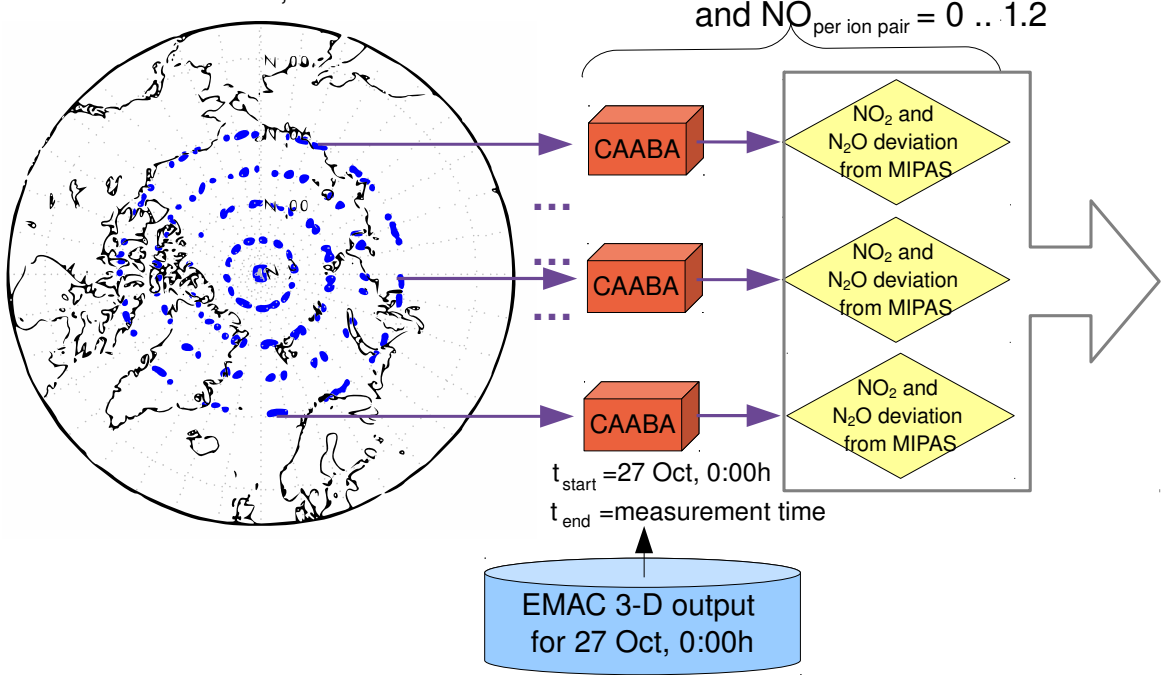

Average deviations (\%) of $\mathrm{NO}_{2}$ and $\mathrm{N}_{2} \mathrm{O}$ at $58 \mathrm{~km}$

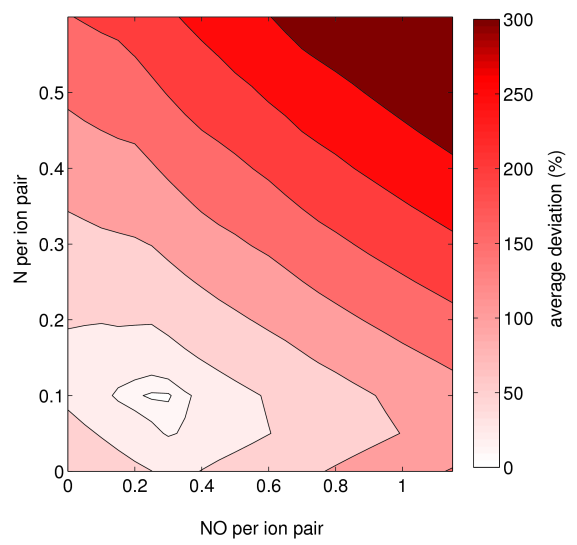

Fig. 8. Datasets, simulations, and postprocessing used to determine the $\mathrm{N}$ and NO production per ion pair that fits best to MIPAS observations. The depicted processing chain is performed for each altitude separately.
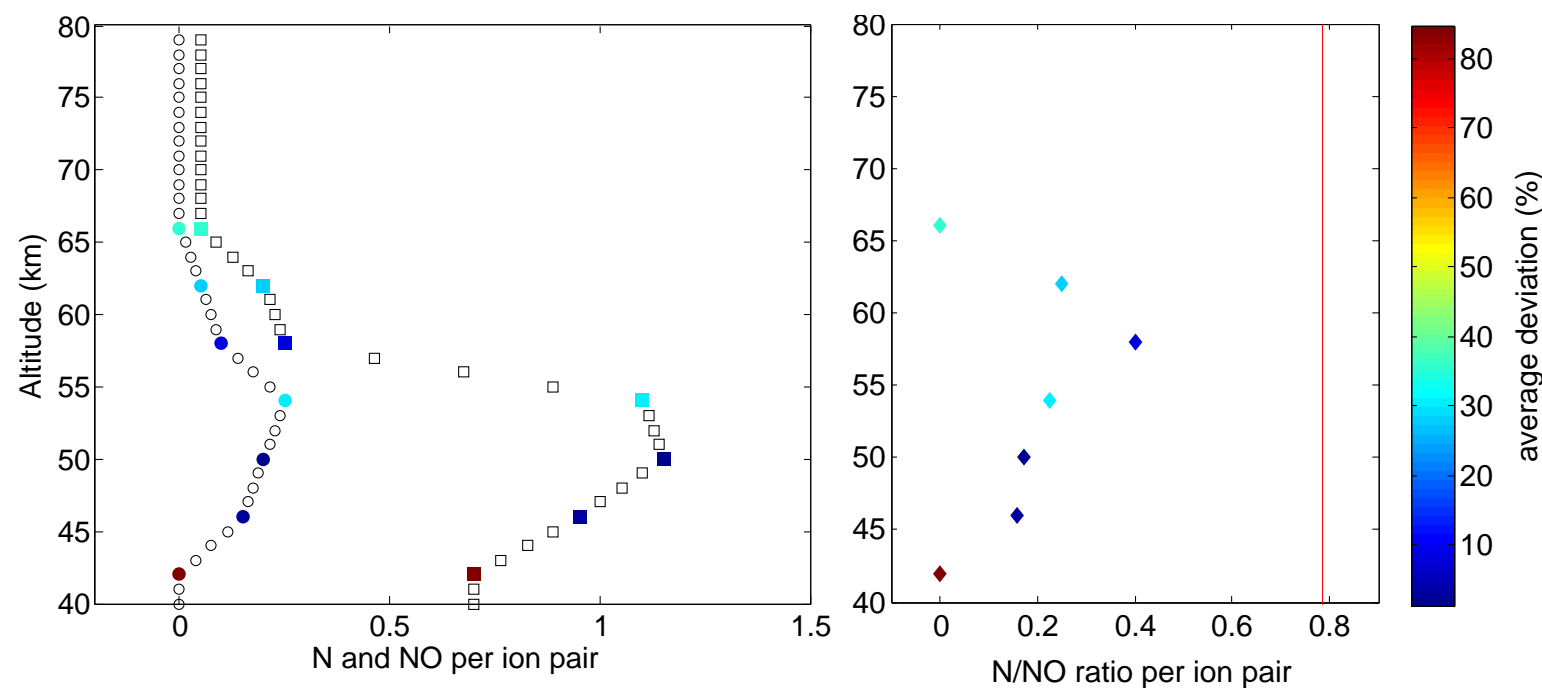

Fig. 9. Left: $\mathrm{N}$ (filled circles) and NO (filled squares) production efficiencies determined from CAABA simulations. The colour indicates the average deviation between model and MIPAS $\mathrm{NO}_{2}$ and $\mathrm{N}_{2} \mathrm{O}$ in percent. Empty circles and squares show the linearly interpolated and extrapolated production efficiencies used in the EMAC model simulations S-SPE-NNOEFF. Right: N/NO ratio per ion pair from CAABA simulations (diamonds) and commonly used value (red line).

maximize at approximately the height of the stratopause (see Fig. 3), possibly indicating a temperature dependent production mechanism.

A modified branching ratio of $\mathrm{N}\left({ }^{4} \mathrm{~S}\right)$ and $\mathrm{NO}$ as suggested by our analysis implies that an important amount of energy is lost by exothermic reactions involved in the reaction chain following the particle event, and hence would contribute to chemical heating.
A linear interpolation was performed to obtain $\mathrm{N}$ and $\mathrm{NO}$ production per ion pair with a resolution of $1 \mathrm{~km}$, also shown in Fig. 9 (empty circles and squares). We use these values subsequently in a 3-D EMAC simulation, hereafter called SSPE-NNOEFF. Except for these height dependent N/NO production coefficients, the simulation was identical to S-SPE. 
EMAC S-SPE-NNOEFF

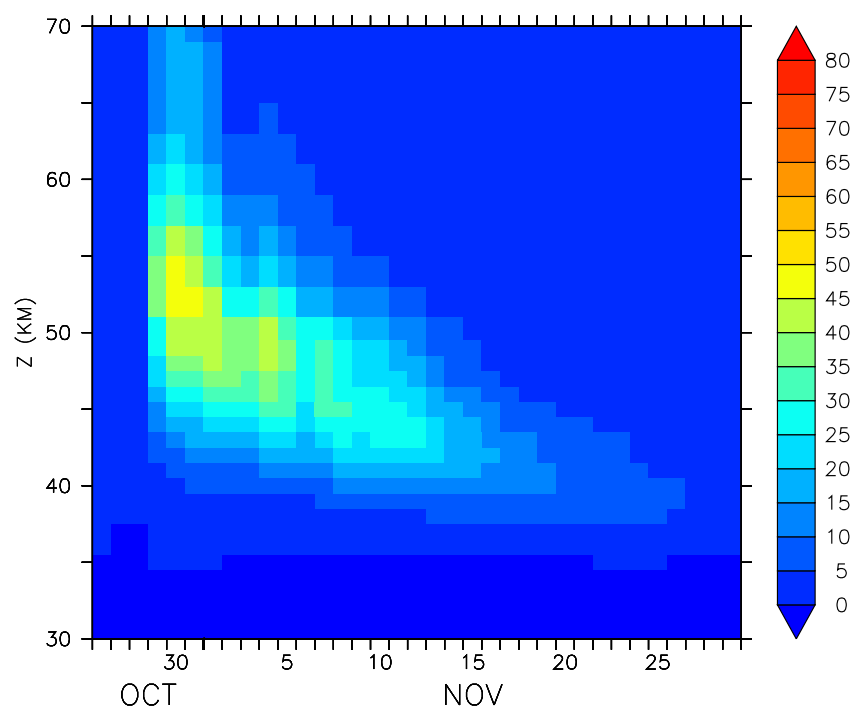

Fig. 10. $\mathrm{NO}_{2}$ changes (ppbv) for $70-90^{\circ} \mathrm{N}$ relative to 26 October 2003 for simulation S-SPE-NNOEFF.

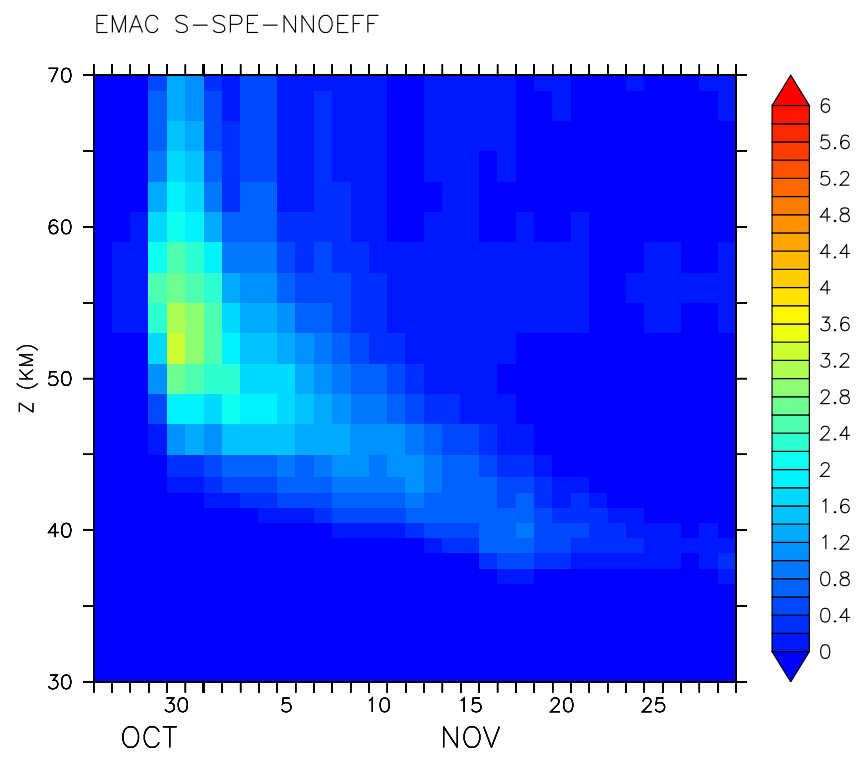

Fig. 11. Same as Fig. 10 but for $\mathrm{N}_{2} \mathrm{O}$ changes (ppbv).

\subsection{Evaluation of the improved parameterization}

The SPE effects on the polar chemistry in the S-SPENNOEFF simulation are now evaluated. Firstly, simulated $\mathrm{NO}_{2}$ (Fig. 10) and $\mathrm{N}_{2} \mathrm{O}$ (Fig. 11) are compared to the MIPAS observations similar to the evaluation of the simulation S-SPE above. In the stratosphere and lower mesosphere the location of the peak values of $\mathrm{NO}_{2}$ with respect to time and altitude is similar for EMAC and MIPAS (compare Figs. 10 and 4a). The magnitude of the first maximum at the end of October reaches approximately $50-60 \mathrm{ppbv}$. The agree- ment with MIPAS is better compared to the simulation SSPE, because the maximum between 55 and $60 \mathrm{~km}$ is similarly pronounced in the model and the observations, whereas $\mathrm{NO}_{2}$ from simulation S-SPE showed a very broad maximum stretching from 50 to $70 \mathrm{~km}$ (Fig. 4b).

Note however that especially in the second half of November in the upper stratosphere the model appears to underestimate $\mathrm{NO}_{2}$. Geomagnetic-activity related $\mathrm{NO}_{\mathrm{x}}$ enhancements are at this time mainly found in the mesosphere, indicating that there might be problems concerning the model $\mathrm{NO}_{\mathrm{y}}$ partitioning, see also Sect. 4.3.

The enhancements in $\mathrm{N}_{2} \mathrm{O}$ shown in Fig. 11 are drastically reduced compared to the simulation S-SPE (Fig. 5b), and are now in satisfactory agreement with the MIPAS observations (Fig. 5a). The maximum during the SPE is located at around $55 \mathrm{~km}, 5 \mathrm{~km}$ below the maximum found by MIPAS. In the observations, $\mathrm{N}_{2} \mathrm{O}$ enhancements reach $4.5 \mathrm{ppbv}$, which is overestimated by the model at approximately 6 ppbv. Note that the precision and standard error of the MIPAS profile ensemble amount to $0.08 \mathrm{ppbv}$ and $0.14 \mathrm{ppbv}$ at $50 \mathrm{~km}$ on 31 October, when the $\mathrm{N}_{2} \mathrm{O}$ mixing ratio maximises. Assuming that the sampling error is smaller than these errors, there remains a bias between model and measurements.

\subsection{Further SPE-induced composition changes}

The enhancements of both $\mathrm{NO}_{\mathrm{x}}$ and $\mathrm{OH}$ results in severe ozone depletion in the polar caps. Fig. 12 shows MIPAS (a) and EMAC S-SPE-NNOEFF (b) ozone changes in percent relative to 26 October 2003. Both MIPAS and EMAC S-SPENNOEFF results show an ozone depletion of up to $50 \%$ in the upper stratosphere. In the mesosphere, short-term ozone depletion exceeds 50\%. In the sunlit Southern Hemisphere mesosphere ozone loss is less severe (not shown), which can be explained by differences in the ambient $\mathrm{HO}_{\mathrm{x}}$ production (Rohen et al., 2005) and the shorter lifetime of $\mathrm{NO}_{\mathrm{x}}$. An additional estimate of ozone depletion is obtained by comparing the EMAC S-SPE-NNOEFF and S-NOSPE simulations, shown in Fig. 12c. It is evident that the SPE related ozone depletion is significant and not an artefact of the illustration technique. However, stratospheric ozone depletion due to the SPE appears to be overestimated by up to 20 percentage points, and contributions to ozone loss from intrinsic processes appear to play a non-negligible role.

Ozone depletion is restricted to altitudes above $35 \mathrm{~km}$, thus the expected impact on total ozone content (TOC) is small. The effect of the SPE on TOC can be estimated by comparing EMAC S-SPE-NNOEFF TOC and S-NOSPE TOC for the area north of $70^{\circ} \mathrm{N}$, shown as the solid and dashed line, respectively, in Fig. 13. Before the SPE, both simulations show almost identical behaviour of TOC. Deviations such as around 22 October are eliminated by the nudging on the relaxation e-folding timescales. From 28 October onwards, a reduction of approximately $5 \mathrm{DU}$ is evident, growing to $10 \mathrm{DU}$ at the end of November. Note that the dominating 


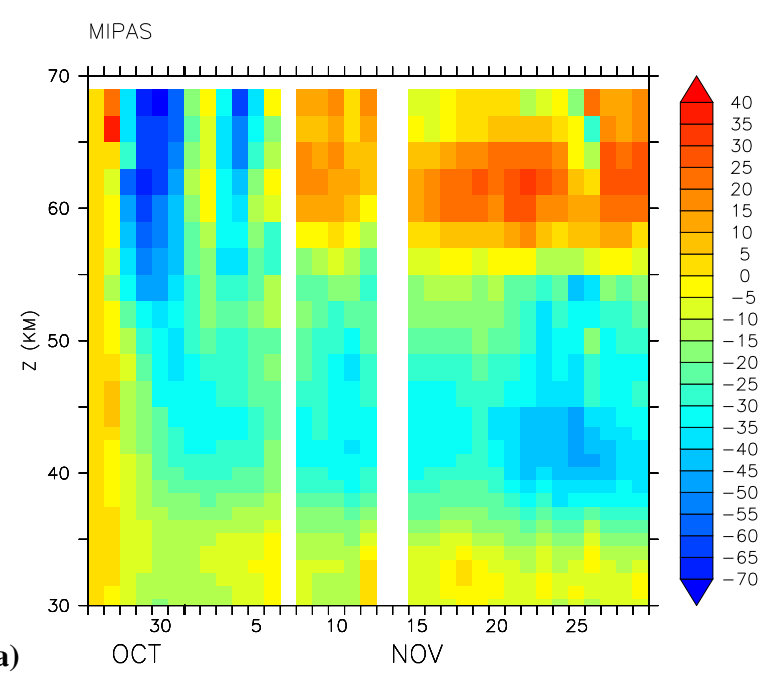

EMAC S-SPE-NNOEFF

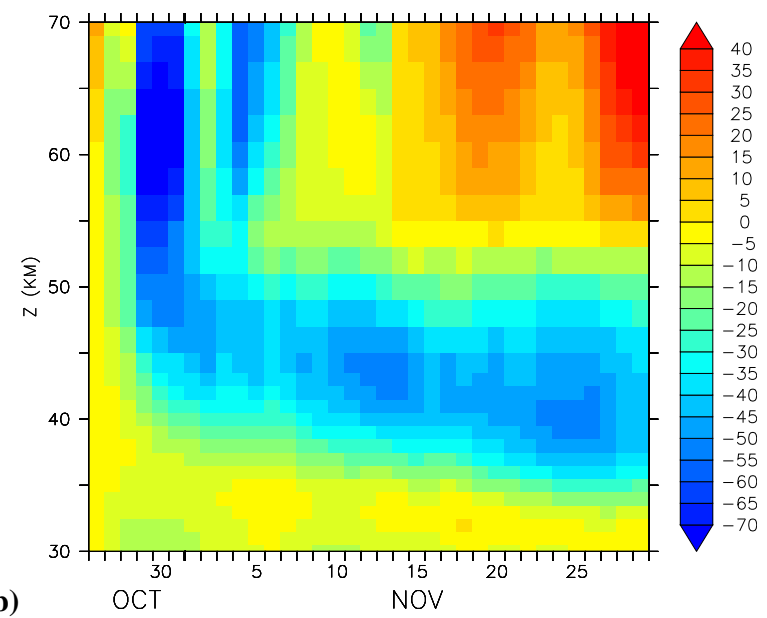

EMAC S-SPE-NNOEFF - S-NOSPE

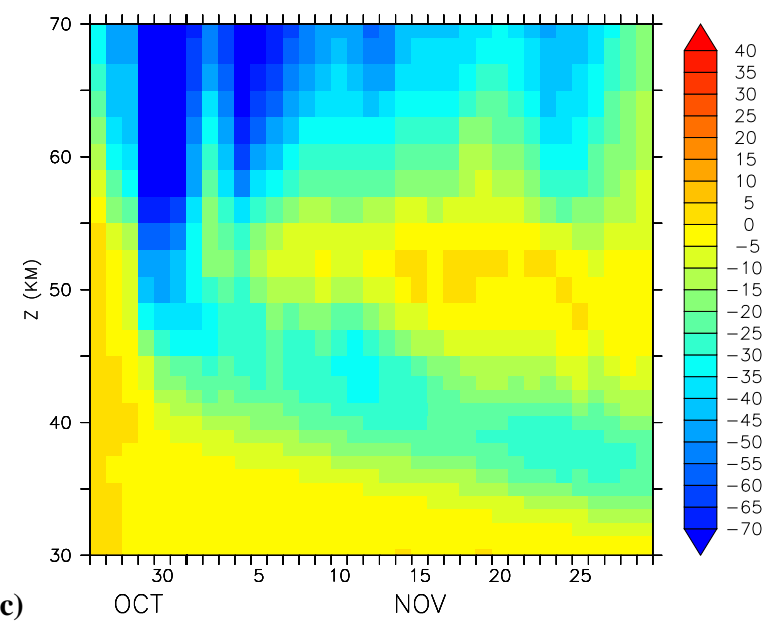

Fig. 12. Ozone mixing ratio percentage change; (a) MIPAS, relative to 26 October, (b) EMAC S-SPE-NNOEFF, relative to 26 October, (c) difference between EMAC S-SPE-NNOEFF and S-NOSPE.

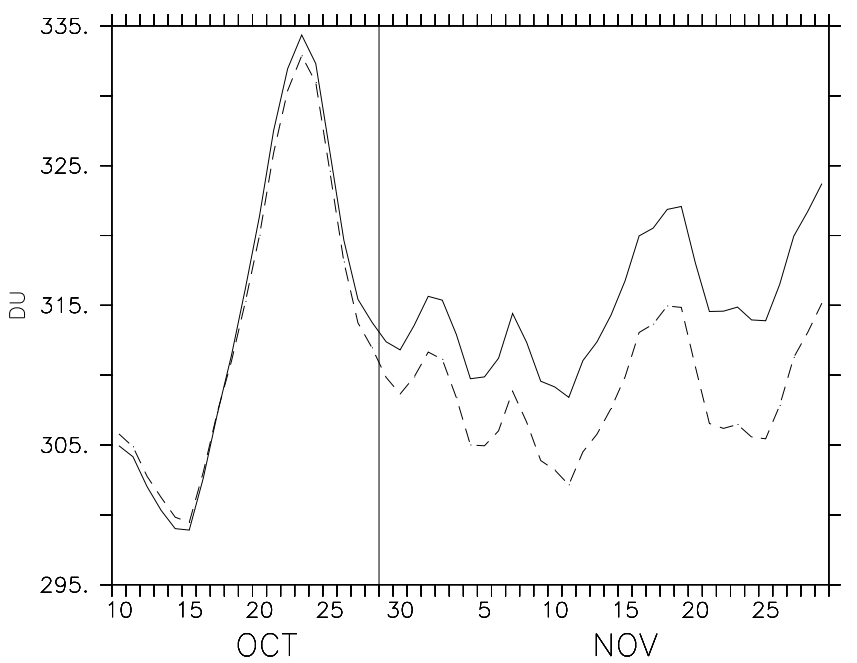

Fig. 13. Change of total ozone between the simulations S-SPENNOEFF (dashed line) and S-NOSPE (solid line) in the region 70$90^{\circ} \mathrm{N}$.

variations on a timescale of a few days are synchronous because both simulations are nudged to the observed meteorology. The increase in TOC loss during the course of November is likely due to the downward transport of $\mathrm{NO}_{\mathrm{x}}$ and associated ozone depletion (see above), becoming more and more important for TOC. This TOC loss is greater than simulated by Vogel et al. (2008), who reported an upper limit of 5.5 DU at the end of November. However, because a different geographical area was used and because of the large influence of natural variations, these results are unlikely to contradict each other.

The $\mathrm{OH}$ radical is one of the direct products of SPEs as seen above. The production parameterization leads to shortterm enhancements of $\mathrm{OH}$ in the upper stratosphere and mesosphere of about 5 ppbv as shown in Fig. 14. MIPAS does not measure $\mathrm{OH}$, but several reactions (e.g. outlined in Jackman et al., 2008) involving $\mathrm{HO}_{\mathrm{x}}$ source gases also lead to the buildup of chlorine containing trace gases. For example, von Clarmann et al. (2005) and López-Puertas et al. (2005b) have presented evidence for buildup of $\mathrm{HOCl}$ and $\mathrm{ClONO}_{2}$ in the stratosphere using MIPAS observations. Figure 15 depicts measured (left) and simulated (right) $\mathrm{HOCl}$ enhancements. As reported by von Clarmann et al. (2005), the enhancement commences at the start of the SPE and decreases exponentially afterwards, such that there is no evidence for $\mathrm{HOCl}$ enhancements after 5 November. The maximum of about $0.25 \mathrm{ppbv}$ is located at $40 \mathrm{~km}$. The model reproduces this behaviour well, but overestimates the enhancement by about 0.05 ppbv. For $\mathrm{ClONO}_{2}$, the start of the enhancement is delayed by 1-2 days with respect to the SPE and lasts for several weeks as shown in Fig. 16a. López-Puertas et al. (2005b) attributed this behaviour to the relatively slow reaction of the enhanced $\mathrm{NO}_{2}$ to $\mathrm{ClONO}_{2}$, providing a reservoir 


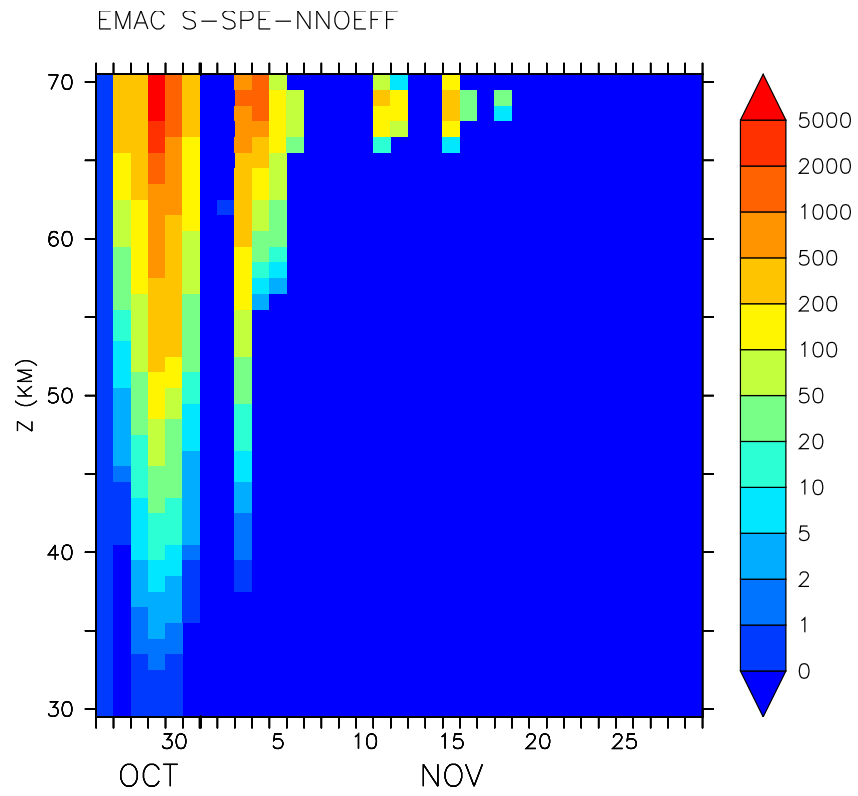

Fig. 14. Simulated change (pptv) of $\mathrm{OH}$ for $70-90^{\circ} \mathrm{N}$ with respect to 26 October 2003.

for the chlorine containing gases. The model (Fig. 16b) qualitatively reproduces the $\mathrm{ClONO}_{2}$ maximum between 32 and $42 \mathrm{~km}$ in the weeks after the SPE, but underestimates the buildup by about $50 \%$.

Figure 17 depicts changes of $\mathrm{N}_{2} \mathrm{O}_{5}$ mixing ratios in the same manner. Qualitatively the model reproduces the slow buildup of $\mathrm{N}_{2} \mathrm{O}_{5}$ centred around an altitude of $40 \mathrm{~km}$. Clearly, the measured enhancements of up to 2 ppbv are overestimated by up to a factor of 5. This discrepancy was present in all simulations (S-SPE, S-SPE-FUNKE and SSPE-NNOEFF). While the reactions that convert $\mathrm{NO}_{\mathrm{x}}$ to $\mathrm{N}_{2} \mathrm{O}_{5}$ are sensitive to temperature, the agreement between MIPAS and EMAC temperature at $40 \mathrm{~km}$ (see Fig. 3) implies that the disagreement is not related to temperature effects. Instead, the lack of cluster ion chemistry in EMAC is probably causing this disagreement. Stiller et al. (2005) found that after the conversion of $\mathrm{NO}_{\mathrm{x}}$ to $\mathrm{N}_{2} \mathrm{O}_{5}$ the latter reacts with cluster ions to form $\mathrm{HNO}_{3}$. Since this reaction is not considered in EMAC, the $\mathrm{N}_{2} \mathrm{O}_{5}$ enhancements are much stronger than observed.

Indeed, EMAC simulations predict only an $\mathrm{HNO}_{3}$ mixing ratio increase of $0.6 \mathrm{ppbv}$ (see Fig. 7 in the supplement) in late November, compared to enhancements of $1-5 \mathrm{ppbv}$ reported also by López-Puertas et al. (2005b) using MIPAS observations. Note that EMAC also does not reproduce the short-term increase of $\mathrm{HNO}_{3}$ during and in the days after the SPE, similar to other models (see e.g. Jackman et al., 2008). As discussed by Verronen et al. (2008), the observed shortterm increase is probably related to ion-ion recombination reactions missing in EMAC.
If MIPAS and model $\mathrm{NO}_{\mathrm{y}}$ (here: $\mathrm{NO}_{2}+2 \times \mathrm{N}_{2} \mathrm{O}_{5}+\mathrm{HNO}_{3}$ $+\mathrm{ClONO}_{2}$ ) are compared (see supplement Fig. 11), a good agreement is found. The model overestimations of $\mathrm{N}_{2} \mathrm{O}_{5}$ and $\mathrm{ClONO}_{2}$ especially toward the end of November compensate the more rapid loss of $\mathrm{NO}_{2}$ in the model. This indicates problems concerning the partitioning within the $\mathrm{NO}_{\mathrm{y}}$ family and has already been reported by Brühl et al. (2007).

\subsection{Dynamical effects}

In sunlit areas, the SPE induced perturbance of ozone can potentially lead to temperature changes because of its radiative importance. In order to examine SPE effects on temperature and winds, two further simulations were carried out where the nudging of tropospheric meteorology was turned off. The two simulations are otherwise equivalent to the simulations S-NOSPE and S-SPE-NNOEFF, respectively. The simulations were started on 1 October 2003 from the same initial conditions as all other simulations presented here. For the Halloween events, effects on dynamics are only expected to play a role in the sunlit southern polar area. There, the model predicts an ozone loss of $0.5-1 \mathrm{ppmv}$, equivalent to $30 \%-70 \%$, in the lower mesosphere (not shown), but prevalent only during the SPE period. The associated temperature changes in the area $70^{\circ} \mathrm{S}-90^{\circ} \mathrm{S}$ relative to the simulation without the SPE are depicted in Fig. 18a. An average cooling of up to $2.6 \mathrm{~K}$ in the lower mesosphere is evident during the first week after the SPE. The cooling is strongest at $60 \mathrm{~km}$. Jackman et al. (2007) found a cooling up to $2.6 \mathrm{~K}$ at $65 \mathrm{~km}$ altitude and $90^{\circ} \mathrm{S}$ from their model simulations. If the EMAC analysis is restricted to $90^{\circ} \mathrm{S}$ as in Jackman et al. (2007), the maximum cooling amounts to $3.0 \mathrm{~K}$ at $60 \mathrm{~km}$. Therefore, the magnitude of the cooling is comparable, although there is a five kilometer altitude offset between the areas of the largest response. Using a mechanistic model, Becker and von Savigny (2010) also found a similar response $(-3 \mathrm{~K})$. For comparison, a model study by Krivolutsky et al. (2006) of the stronger July 2000 SPE found a cooling of up to $8 \mathrm{~K}$ centered around $60 \mathrm{~km}$. Around the stratopause the cooling lasts longest and is still discernible at the end of November. The observed cooling is likely due to the changes in UV absorption. As a consequence, the model predicts a change of $3 \mathrm{~m} / \mathrm{s}$ in the zonal mean wind (Fig. 18b), maximizing at $70 \mathrm{~km}$. Changes in the meridional wind were not significant (not shown). These dynamical effects will be subject to further analyses in the future.

\section{Summary and conclusions}

A new submodel for the parameterization of solar proton events has been implemented in the atmospheric chemistry general circulation model EMAC and tested for the 2003 Halloween storm period. The chemistry submodels of EMAC are also contained in the box model CAABA, 

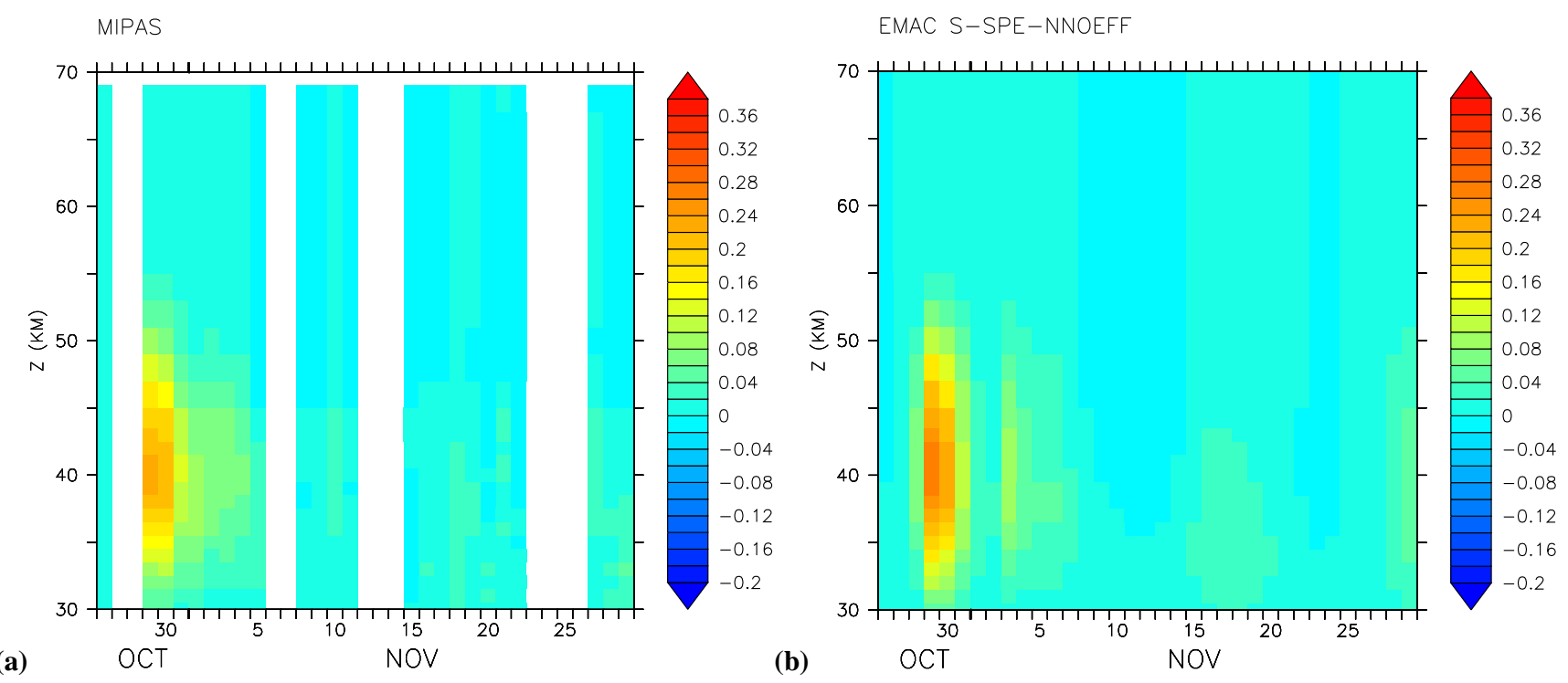

Fig. 15. $\mathrm{HOCl}$ changes (ppbv) for $70-90^{\circ} \mathrm{N}$ relative to 26 October 2003; (a) MIPAS, (b) EMAC simulation S-SPE-NNOEFF.
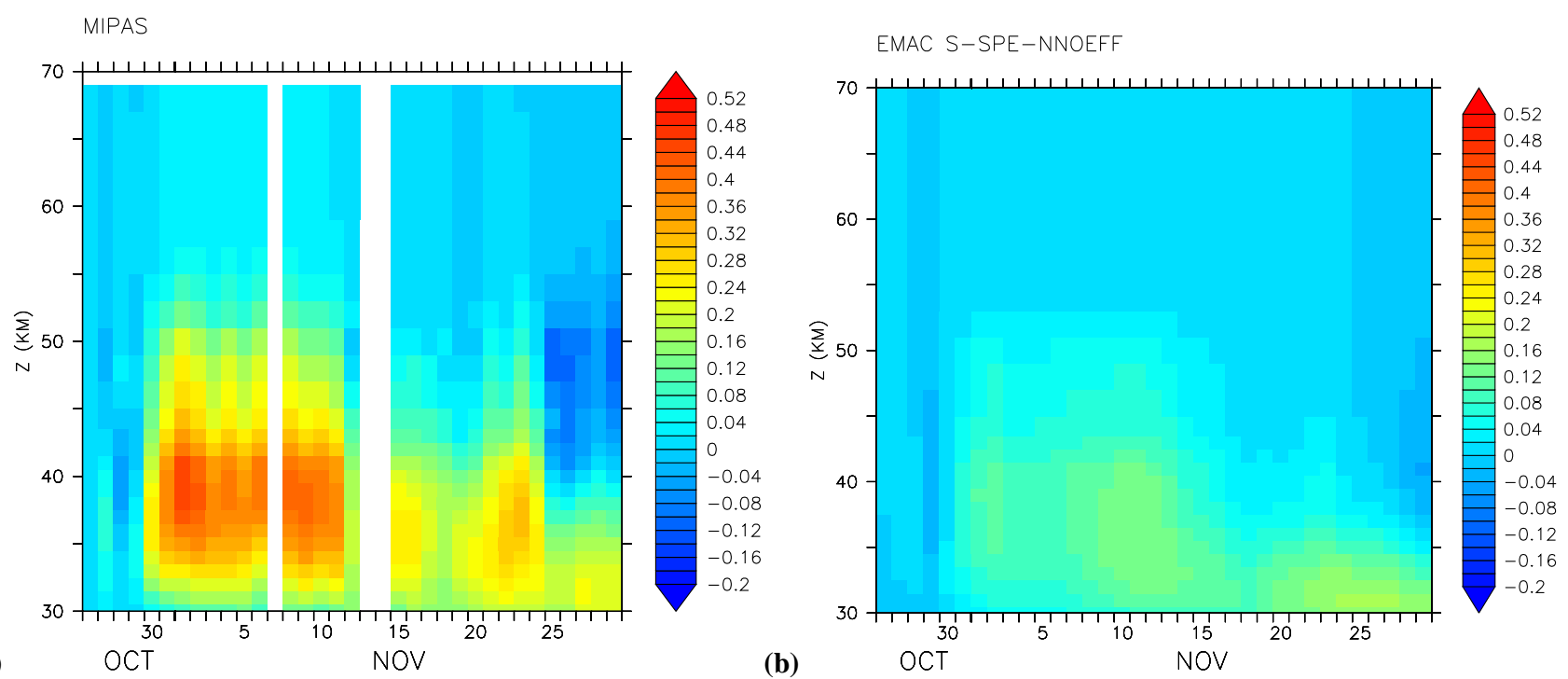

Fig. 16. $\mathrm{ClONO}_{2}$ changes (ppbv) for $70-90^{\circ} \mathrm{N}$ relative to 26 October 2003; (a) MIPAS, (b) EMAC simulation S-SPE-NNOEFF.

allowing to assess the influence of temperature on SPEinduced changes of chemical species through temperature dependent reaction rates. In addition to this feature, EMAC is also well suited for this type of study because of the possibility to relax the model meteorology to reanalysis datasets and because of its interactive chemistry.

The internal calculation of ionization rates, based on particle flux measurements, was evaluated against published ionization rates. One of the parameters of the employed Bethe energy-range relationship was modified by $30 \%$ in order to reach better agreement. MIPAS observations were used to evaluate $\mathrm{NO}_{2}, \mathrm{~N}_{2} \mathrm{O}, \mathrm{N}_{2} \mathrm{O}_{5}, \mathrm{HOCl}, \mathrm{ClONO}_{2}$, and $\mathrm{O}_{3}$ which have all been shown to be affected by SPEs. For $\mathrm{N}_{2} \mathrm{O}$ the model overestimates SPE related production grossly. Therefore, the production of $\mathrm{N}$ and $\mathrm{NO}$ per ion pair was modified using results from box model calculations: CAABA simulations were carried out for all individual MIPAS measurements of $\mathrm{NO}_{2}$ and $\mathrm{N}_{2} \mathrm{O}$ during and shortly after the SPEs, employing different $\mathrm{N} / \mathrm{NO}$ production efficiencies. Using the optimized height dependent production efficiencies in the 3-D model yielded good agreement between EMAC and MIPAS for $\mathrm{NO}_{2}, \mathrm{~N}_{2} \mathrm{O}$ and $\mathrm{O}_{3}$. However, due to problems 

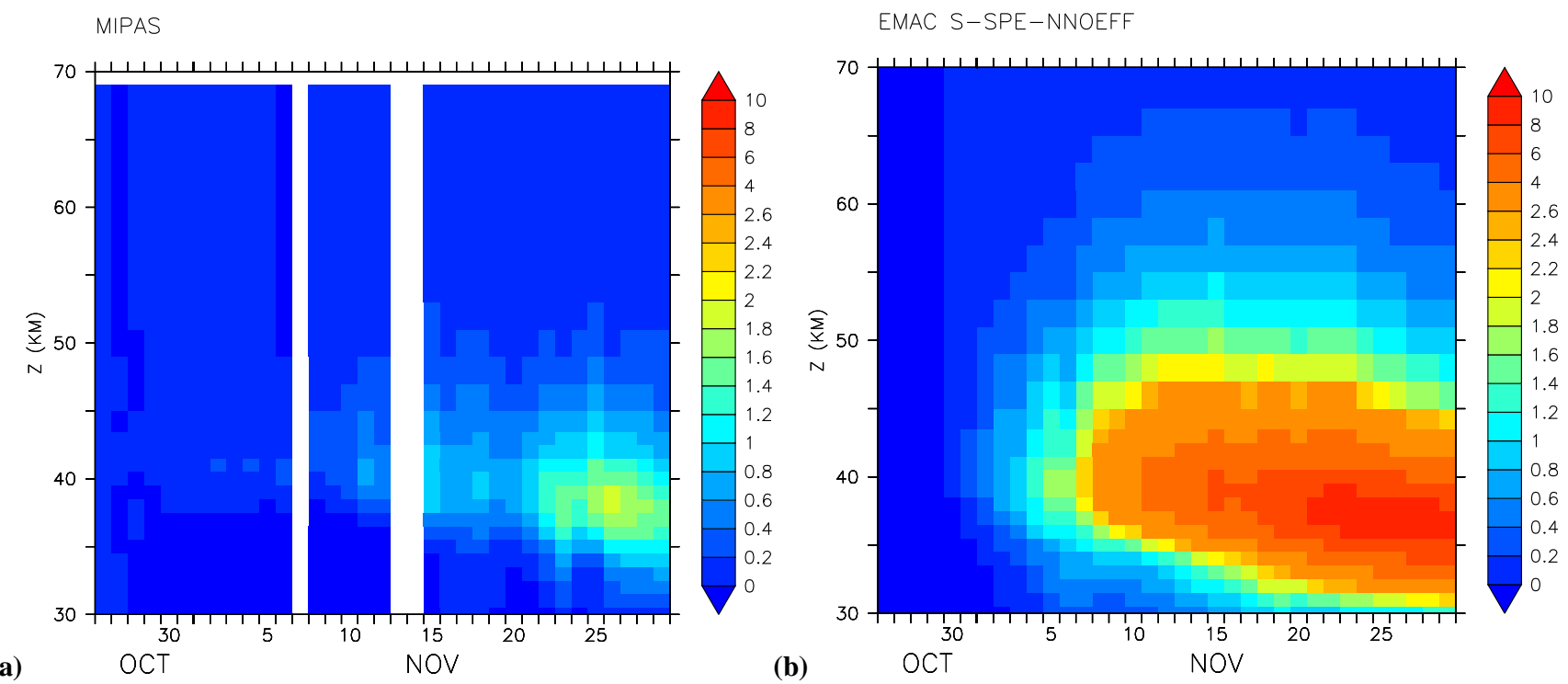

Fig. 17. $\mathrm{N}_{2} \mathrm{O}_{5}$ changes (ppbv) for $70-90^{\circ} \mathrm{N}$ relative to 26 October 2003; (a) MIPAS, (b) EMAC simulation S-SPE-NNOEFF.
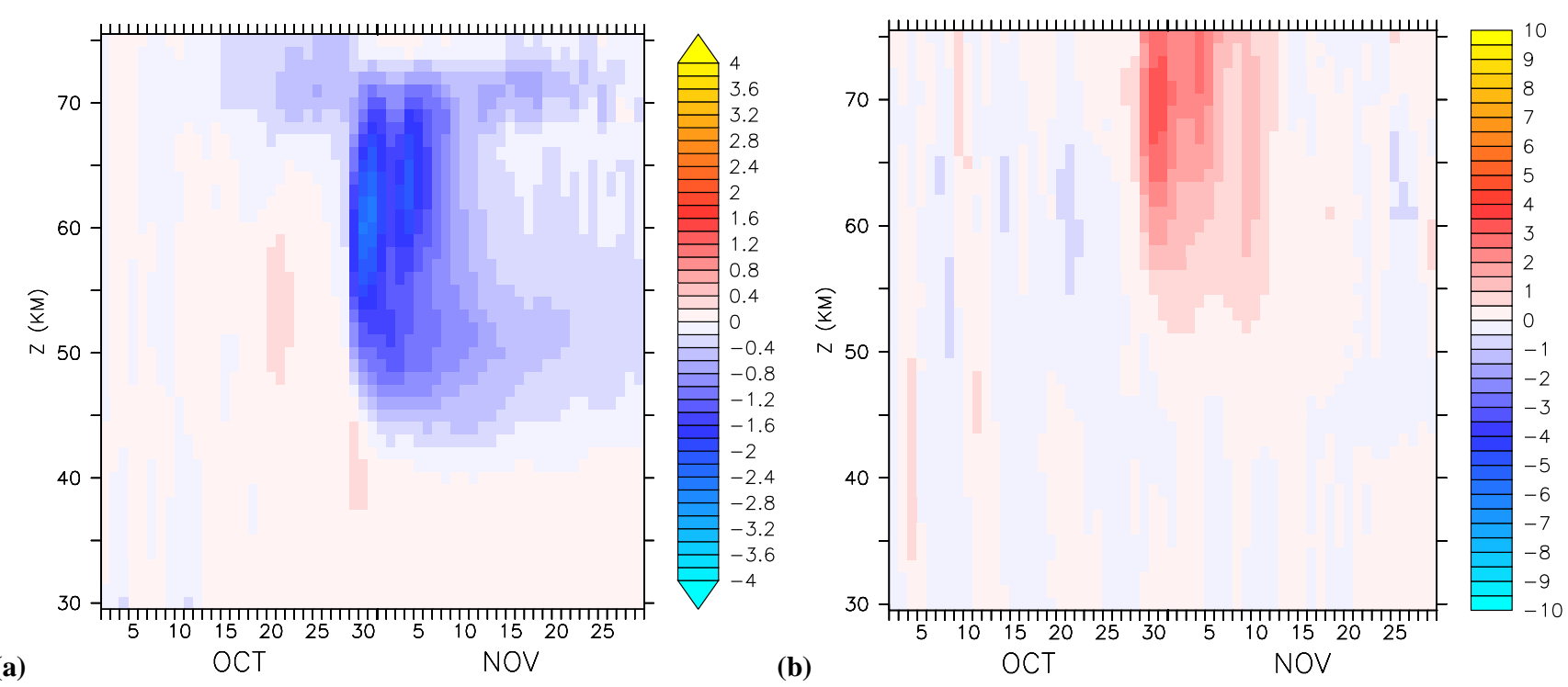

Fig. 18. (a) Change of temperature (K) between two free running simulations with and without SPE submodel turned on. (b) Change of zonal mean wind $(\mathrm{m} / \mathrm{s})$.

concerning the $\mathrm{NO}_{\mathrm{y}}$ partitioning in the model as well as missing cluster ion chemistry, disagreements persist for $\mathrm{HNO}_{3}$, $\mathrm{ClONO}_{2}$ and $\mathrm{N}_{2} \mathrm{O}_{5}$. Despite these discrepancies the SPE induced ozone depletion in the polar Northern Hemisphere was shown to be in very good agreement with MIPAS throughout the middle atmosphere. Good agreement of $\mathrm{HOCl}$ as an indicator for perturbed $\mathrm{HO}_{\mathrm{x}}$ was found. Both the modification of the energy-range relationship as well as the modification of the N/NO production efficiency will need to be tested further in EMAC as well as other general circulation mod- els that include chemistry in order to examine their validity. In case further evidence mounts that such modifications are necessary to reconcile models and observations, further laboratory experiments are also conceivable.

Further results of this study include:

1. Significant changes in chemistry and dynamics already arise due to seasonal variation only, as can be shown by comparing SPE-simulations to an additional simulation without SPE. For example, stratospheric ozone loss 
reaches $50 \%$ at the end of November when compared to ozone before the SPEs, but only $35 \%$ when compared to a simulation where the SPE submodel was turned off.

2. The loss of total column ozone amounts to approximately 5 DU immediately after the SPEs. At the end of November, when $\mathrm{NO}_{\mathrm{x}}$ and associated ozone loss reach lower altitudes, total column loss approaches $10 \mathrm{DU}$, an amount similar to natural variability and slightly larger than reported by previous studies.

3. In the Southern Hemisphere, EMAC shows an SPEinduced cooling of about $2.5 \mathrm{~K}$ in agreement with another study which included more complex feedbacks that can play a role in the mesosphere-lowerthermosphere.

\section{Supplementary material related to this article is available online at: http://www.atmos-chem-phys.net/10/7285/2010/ acp-10-7285-2010-supplement.zip.}

Acknowledgements. This research was funded by the ProSECCO, TIES, and MANOXUVA projects within the DFG SPP 1176 CAWSES. We thank all MESSy developers and users for their support. MIPAS level-1b data were provided by ESA. We thank Johannes Plieninger for the MIPAS error budget calculations. The particle fluxes were provided by the NOAA GOES team (USA) via their website. We have used the Ferret program (http://www.ferret. noaa.gov) from NOAA's Pacific Marine Environmental Laboratory for creating some of the graphics in this paper.

The service charges for this open access publication have been covered by the Max Planck Society.

Edited by: F.-J. Lübken

\section{References}

Baumgaertner, A. J. G. and Brühl, C.: Emission inventory for CCMVal model simulations 1960-2000, tech. rep., http://www2.mpch-mainz.mpg.de/ abaumg/publications/ EmissionsCCMVal.pdf, 2008.

Baumgaertner, A. J. G., Jöckel, P., and Brühl, C.: Energetic particle precipitation in ECHAM5/MESSy1 - Part 1: Downward transport of upper atmospheric $\mathrm{NO}_{\mathrm{x}}$ produced by low energy electrons, Atmos. Chem. Phys., 9, 2729-2740, doi:10.5194/acp-92729-2009, 2009.

Becker, E. and von Savigny, C.: Dynamical heating of the polar summer mesopause induced by solar proton events, J. Geophys. Res., 115, D00I18, doi:10.1029/2009JD012561, 2010.

Bethe, H. and Ashkin, J.: Experimental Nuclear Physics, Volume I, chap. II Passage of Radiations through Matter, John Wiley and Sons, New York, USA, 166-357, 1953.

Brasseur, G. P. and Solomon, S.: Aeronomy of the Middle Atmosphere, D. Reidel Publishing Company, 2nd revised edn., 1986.
Brühl, C., Steil, B., Stiller, G., Funke, B., and Jöckel, P.: Nitrogen compounds and ozone in the stratosphere: comparison of MIPAS satellite data with the chemistry climate model ECHAM5/MESSy1, Atmos. Chem. Phys., 7, 5585-5598, doi:10.5194/acp-7-5585-2007, 2007.

Crutzen, P. J., Isaksen, I. S. A., and Reid, G. C.: Solar proton events - Stratospheric sources of nitric oxide, Science, 189, 457-459, doi:10.1126/science.189.4201.457, 1975.

Dalgarno, A.: Atmospheric reactions with energetic particles, Space Res., 7, 849-861, 1967.

Fabian, P., Pyle, J. A., and Wells, R. J.: The August 1972 solar proton event and the atmospheric ozone layer, Nature, 277, 458460, doi:10.1038/277458a0, 1979.

Funke, B., García-Comas, M., López-Puertas, M., Glatthor, N., Stiller, G. P., von Clarmann, T., Semeniuk, K., and McConnell, J. C.: Enhancement of $\mathrm{N}_{2} \mathrm{O}$ during the October/November 2003 solar proton events, Atmos. Chem. Phys., 8, 3805-3815, doi:10.5194/acp-8-3805-2008, 2008.

Heath, D. F., Krueger, A. J., and Crutzen, P. J.: Solar Proton Event: Influence on Stratospheric Ozone, Science, 197, 886-889, doi: 10.1126/science.197.4306.886, 1977.

Jackman, C. H.: Ionization Rates for 1963-2005 from Solar Proton Events, SOLARIS website http://strat-www.met.fu-berlin. de/ $\sim$ matthes/sparc/inputdata.html, 2006.

Jackman, C. H. and McPeters, R. D.: Solar Variability and its Effects on Climate, Geophysical Monograph, chap.: The Effect of Solar Proton Events on Ozone and Other Constituents, American Geophysical Union, 141, 305-319, 2004.

Jackman, C. H., Douglass, A. R., Rood, R. B., McPeters, R. D., and Meade, P. E.: Effect of solar proton events on the middle atmosphere during the past two solar cycles as computed using a two-dimensional model, J. Geophys. Res., 95, 7417-7428, doi: 10.1029/JD095iD06p07417, 1990.

Jackman, C. H., DeLand, M. T., Labow, G. J., Fleming, E. L., Weisenstein, D. K., Ko, M. K. W., Sinnhuber, M., and Russell, J. M.: Neutral atmospheric influences of the solar proton events in October-November 2003, J. Geophys. Res., 110, A09S27, doi: 10.1029/2004JA010888, 2005.

Jackman, C. H., Roble, R. G., and Fleming, E. L.: Mesospheric dynamical changes induced by the solar proton events in October-November 2003, Geophys. Res. Lett., 34, L04812, doi:10.1029/2006GL028 328, 2007.

Jackman, C. H., Marsh, D. R., Vitt, F. M., Garcia, R. R., Fleming, E. L., Labow, G. J., Randall, C. E., López-Puertas, M., Funke, B., von Clarmann, T., and Stiller, G. P.: Short- and medium-term atmospheric constituent effects of very large solar proton events, Atmos. Chem. Phys., 8, 765-785, doi:10.5194/acp-8-765-2008, 2008.

Jöckel, P., Sander, R., Kerkweg, A., Tost, H., and Lelieveld, J.: Technical Note: The Modular Earth Submodel System (MESSy) - a new approach towards Earth System Modeling, Atmos. Chem. Phys., 5, 433-444, doi:10.5194/acp-5-433-2005, 2005.

Jöckel, P., Tost, H., Pozzer, A., Brühl, C., Buchholz, J., Ganzeveld, L., Hoor, P., Kerkweg, A., Lawrence, M. G., Sander, R., Steil, B., Stiller, G., Tanarhte, M., Taraborrelli, D., van Aardenne, J., and Lelieveld, J.: The atmospheric chemistry general circulation model ECHAM5/MESSy1: consistent simulation of ozone from the surface to the mesosphere, Atmos. Chem. Phys., 6, 50675104, doi:10.5194/acp-6-5067-2006, 2006. 
Jöckel, P., Kerkweg, A., Pozzer, A., Sander, R., Tost, H., Riede, H., Baumgaertner, A., Gromov, S., and Kern, B.: Development cycle 2 of the Modular Earth Submodel System, Geosci. Model Dev. Discuss., submitted, 2010.

Krivolutsky, A. A., Klyuchnikova, A. V., Zakharov, G. R., Vyushkova, T. Y., and Kuminov, A. A.: Dynamical response of the middle atmosphere to solar proton event of July 2000: Threedimensional model simulations, Adv. Space Res., 37, 16021613,2006

Landgraf, J. and Crutzen, P. J.: An Efficient Method for Online Calculations of Photolysis and Heating Rates., J. Atmos. Sci., 55, 863-878, doi:10.1175/1520-0469(1998)055, 1998.

Lelieveld, J., Brühl, C., Jöckel, P., Steil, B., Crutzen, P. J., Fischer, H., Giorgetta, M. A., Hoor, P., Lawrence, M. G., Sausen, R., and Tost, H.: Stratospheric dryness: model simulations and satellite observations, Atmos. Chem. Phys., 7, 1313-1332, doi:10.5194/acp-7-1313-2007, 2007.

López-Puertas, M., Funke, B., Gil-López, S., von Clarmann, T., Stiller, G. P., Höpfner, M., Kellmann, S., Fischer, H., and Jackman, C. H.: Observation of $\mathrm{NO}_{\mathrm{x}}$ enhancement and ozone depletion in the Northern and Southern Hemispheres after the October-November 2003 solar proton events, J. Geophys. Res., 110, A09S43, doi:10.1029/2005JA011050, 2005a.

López-Puertas, M., Funke, B., Gil-López, S., von Clarmann, T., Stiller, G. P., Höpfner, M., Kellmann, S., Mengistu Tsidu, G., Fischer, H., and Jackman, C. $\mathrm{H} .: \mathrm{HNO}_{3}, \mathrm{~N}_{2} \mathrm{O}_{5}$, and $\mathrm{ClONO}_{2}$ enhancements after the October-November 2003 solar proton events, J. Geophys. Res., 110, doi:10.1029/2005JA011051, 2005b.

Nissen, K. M., Matthes, K., Langematz, U., and Mayer, B.: Towards a better representation of the solar cycle in general circulation models, Atmos. Chem. Phys., 7, 5391-5400, doi:10.5194/acp-75391-2007, 2007.

Porter, H. S., Jackman, C. H., and Green, A. E. S.: Efficiencies for production of atomic nitrogen and oxygen by relativistic proton impact in air, J. Chem. Phys., 65, 154-167, doi: 10.1063/1.432812, 1976.

Rapp, D. and Englander-Golden, P.: Total Cross Sections for Ionization and Attachment in Gases by Electron Impact. I. Positive Ionization, J. Chem. Phys., 43, 1464-1479, doi:10.1063/1. 1696957,1965

Rapp, D., Englander-Golden, P., and Briglia, D. D.: Cross Sections for Dissociative Ionization of Molecules by Electron Impact, J. Chem. Phys., 42, 4081-4085, doi:10.1063/1.1695897, 1965.

Reid, G. C., Solomon, S., and Garcia, R. R.: Response of the middle atmosphere to the solar proton events of AugustDecember, 1989, Geophys. Res. Lett., 18, 1019-1022, doi: 10.1029/91GL01049, 1991.

Roeckner, E., Brokopf, R., Esch, M., Giorgetta, M., Hagemann, S., Kornblueh, L., Manzini, E., Schlese, U., and Schulzweida, U.: Sensitivity of Simulated Climate to Horizontal and Vertical Resolution in the ECHAM5 Atmosphere Model, J. Climate, 19, 3771, doi:10.1175/JCLI3824.1, 2006.

Rohen, G., von Savigny, C., Sinnhuber, M., Llewellyn, E. J., Kaiser, J. W., Jackman, C. H., Kallenrode, M.-B., Schröter, J., Eichmann, K.-U., Bovensmann, H., and Burrows, J. P.: Ozone depletion during the solar proton events of October/November 2003 as seen by SCIAMACHY, J. Geophys. Res., 110, A09S39, doi:
10.1029/2004JA010984, 2005.

Rohen, G. J., von Savigny, C., Llewellyn, E. J., Kaiser, J. W., Eichmann, K.-U., Bracher, A., Bovensmann, H., and Burrows, J. P.: First results of ozone profiles between 35 and $65 \mathrm{~km}$ retrieved from SCIAMACHY limb spectra and observations of ozone depletion during the solar proton events in October/November 2003, Adv. Space Res., 37, 2263-2268, doi:10.1016/j.asr.2005. 03.160, 2006.

Rusch, D. W., Gérard, J.-C., Solomon, S., Crutzen, P. J., and Reid, G. C.: The effect of particle precipitation events on the neutral and ion chemistry of the middle atmosphere-I. Odd nitrogen, Planet. Space Sci., 29, 767-774, doi:10.1016/0032-0633(81) 90048-9, 1981.

Sander, R., Kerkweg, A., Jöckel, P., and Lelieveld, J.: Technical note: The new comprehensive atmospheric chemistry module MECCA, Atmos. Chem. Phys., 5, 445-450, 2005, http://www.atmos-chem-phys.net/5/445/2005/.

Sander, R., Baumgaertner, A. J. G., Gromov, S., Harder, H., Jöckel, P., Kerkweg, A., Kubistin, D., Riede, H., Taraborrelli, D., and Tost, H.: The atmospheric chemistry box model CAABA/MECCA-3.0, Geosci. Model Dev., in preparation, 2010.

Solomon, S., Rusch, D. W., Gerard, J. C., Reid, G. C., and Crutzen, P. J.: The effect of particle-precipitation events on the neutral and ion chemistry of the middle atmosphere, 2, Odd hydrogen, Planet. Space Sci., 29, 885-892, 1981.

Stiller, G. P., Mengistu Tsidu, G., von Clarmann, T., Glatthor, N., Höpfner, M., Kellmann, S., Linden, A., Ruhnke, R., Fischer, H., López-Puertas, M., Funke, B., and Gil-López, S.: An enhanced $\mathrm{HNO}_{3}$ second maximum in the Antarctic midwinter upper stratosphere 2003, J. Geophys. Res., 110, D20303, doi: 10.1029/2005JD006011, 2005.

Verronen, P. T., Funke, B., López-Puertas, M., Stiller, G. P., von Clarmann, T., Glatthor, N., Enell, C.-F., Turunen, E., and Tamminen, J.: About the increase of $\mathrm{HNO}_{3}$ in the stratopause region during the Halloween 2003 solar proton event, Geophys. Res. Lett., 35, L20809, doi:10.1029/2008GL035312, 2008.

Vitt, F. M. and Jackman, C. H.: A comparison of sources of odd nitrogen production from 1974 through 1993 in the Earth's middle atmosphere as calculated using a two-dimensional model, J. Geophys. Res., 101, 6729-6740, doi:10.1029/95JD03386, 1996.

Vogel, B., Konopka, P., Grooß, J.-U., Müller, R., Funke, B., LópezPuertas, M., Reddmann, T., Stiller, G., von Clarmann, T., and Riese, M.: Model simulations of stratospheric ozone loss caused by enhanced mesospheric $\mathrm{NO}_{\mathrm{x}}$ during Arctic Winter 2003/2004, Atmos. Chem. Phys., 8, 5279-5293, doi:10.5194/acp-8-52792008, 2008.

von Clarmann, T., Glatthor, N., Höpfner, M., Kellmann, S., Ruhnke, R., Stiller, G. P., Fischer, H., Funke, B., Gil-López, S., and López-Puertas, M.: Experimental evidence of perturbed odd hydrogen and chlorine chemistry after the October 2003 solar proton events, J. Geophys. Res., 110, A09S45, doi:10.1029/ 2005JA011053, 2005.

Warneck, P.: Cosmic Radiation as a Source of Odd Nitrogen in the Stratosphere, J. Geophys. Res., 77, 6589-6591, doi:10.1029/ JC077i033p06589, 1972.

Weeks, L. H., Cuikay, R. S., and Corbin, J. R.: Ozone Measurements in the Mesosphere During The Solar Proton Event of 2 November 1969, J. Atmos. Sci., 29, 1138-1142, 1972. 
Winters, H. F.: Ionic Adsorption and Dissociation Cross Section for Nitrogen, J. Chem. Phys., 44, 1472-1476, doi:10.1063/1. 1726879, 1966. 